\title{
Archaeological Excavations at the Alamo Acequia, Southwest Hemisfair Plaza, San Antonio, Bexar County, Texas
}

Anne A. Fox

I. Waynne Cox

Follow this and additional works at: https://scholarworks.sfasu.edu/ita

Part of the American Material Culture Commons, Archaeological Anthropology Commons, Environmental Studies Commons, Other American Studies Commons, Other Arts and Humanities Commons, Other History of Art, Architecture, and Archaeology Commons, and the United States History Commons

Tell us how this article helped you.

This Article is brought to you for free and open access by the Center for Regional Heritage Research at SFA ScholarWorks. It has been accepted for inclusion in Index of Texas Archaeology: Open Access Gray Literature from the Lone Star State by an authorized editor of SFA ScholarWorks. For more information, please contact cdsscholarworks@sfasu.edu. 


\section{Archaeological Excavations at the Alamo Acequia, Southwest Hemisfair Plaza, San Antonio, Bexar County, Texas}

\section{Creative Commons License}

\section{(c) (1) (8)}

This work is licensed under a Creative Commons Attribution-NonCommercial 4.0 International License 


\section{ARCHAEOLOGICAL EXCAVATIONS AT THE ALAMO ACEQUIA, SOUTHWEST HEMISFAIR PLAZA, SAN ANTONIO, BEXAR COUNTY, TEXAS}

Anne A. Fox and I. Waynne Cox

With an Appendix by Maureen Brown

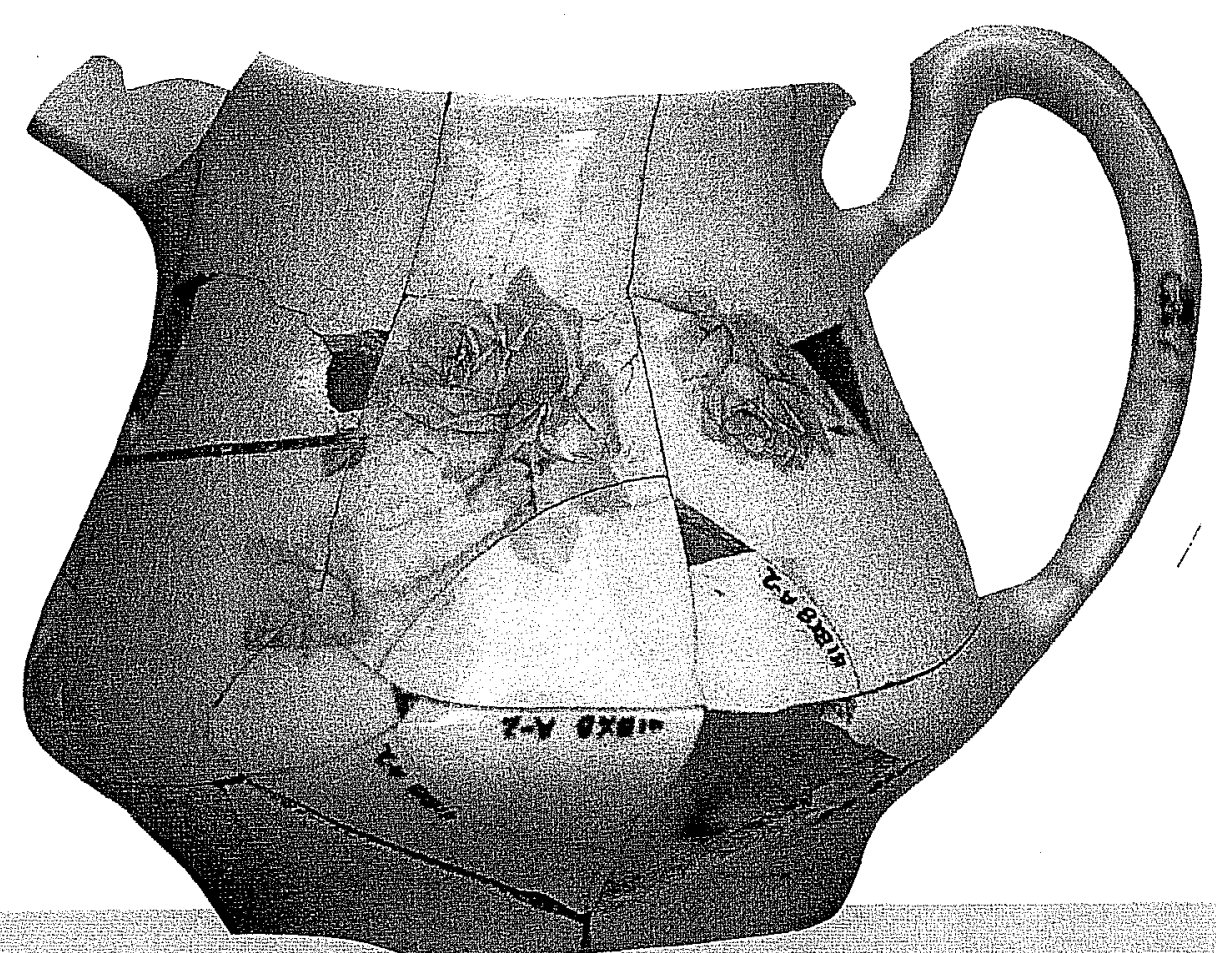

Center for Archaeological Research, The University of Texas at San Antonio, Archaeological Survey Report, No. 192, 1990 



\section{ARCHAEOLOGICAL EXCAVATIONS AT THE ALAMO ACEQUIA, SOUTHWEST HEMISFAIR PLAZA, SAN ANTONIO, BEXAR COUNTY, TEXAS}

Anne A. Fox and I. Waynne Cox

With An Appendix by Maureen Brown

Center for Archaeological Research The University of Texas at San Antonio ${ }^{8}$ Archaeological Survey Report, No. 192 
The following information is provided in accordance with the General Rules of Practice and Procedure, Chapter 41.11 (Investigative Reports), Texas Antiquities Committee:

1. Type of investigation: archaeological testing and monitoring;

2. Project name: Southwest HemisFair Plaza/Acequia Madre;

3. County: Bexar;

4. Principal investigator: Jack D. Eaton; coprincipal investigator and field director: Anne A. Fox;

5. Name and location of sponsoring agency: Day \& Zimmerman, Inc.;

6. Texas Antiquities Committee Permit No. 732;

7. Published by the Center for Archaeological Research, The University of Texas at San Antonio, San Antonio, Texas 78285-0658, 1990.

This book is printed on acid-free paper (Cougar No. 1 Opaque offset). A list of publications offered by the Center for Archaeological Research can be obtained by sending $\$ 1.00$ to the Center for Archaeological Research, The University of Texas at San Antonio, San Antonio, Texas 78285-0658. 


\begin{abstract}
In January 1989, the Center for Archaeological Research, The University of Texas at San Antonio conducted archaeological testing of the Alamo Acequia Madre at the southwest corner of HemisFair Plaza for the City of San Antonio. Six test trenches were excavated across the acequia, and it was found that the stone lining on the east wall is, in most areas, in relatively good condition, but the west wall has been removed. The bottom two to three feet of the acequia contains an accumulation of household trash discarded into it after the acequia ceased to hold water. Above this in some sections there is an accumulation of metal junk such as old bed springs and other furniture parts, along with a great deal of demolition debris from the surrounding house lots. The entire area is capped by layers of gravel and topsoil brought in at the time of the construction of HemisFair. Additional test trenching around buildings in the area to the north revealed that the fill depth was as much as two and one-half feet.
\end{abstract}





\section{TABLE OF CONTENTS}

ABSTRACT $\ldots \ldots \ldots \ldots \ldots \ldots \ldots \ldots \ldots \ldots \ldots \ldots \ldots \ldots \ldots \ldots \ldots \ldots$

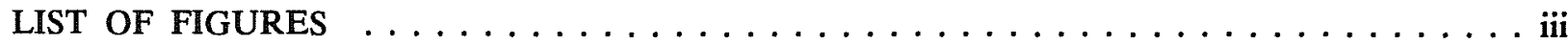

LIST OF TABLES $\ldots \ldots \ldots \ldots \ldots \ldots \ldots \ldots \ldots \ldots \ldots \ldots \ldots \ldots \ldots \ldots \ldots$ iii

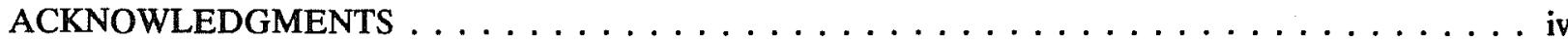

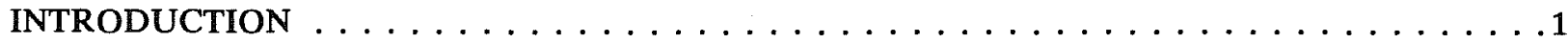

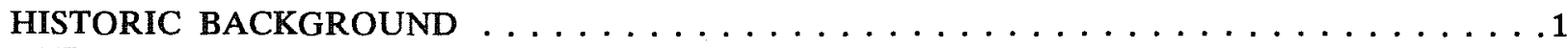

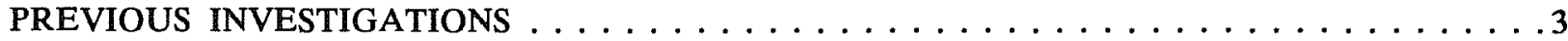

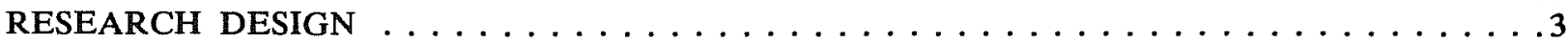

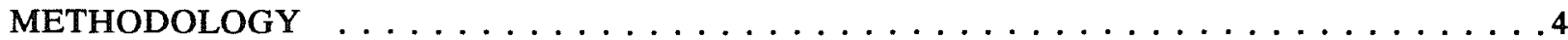

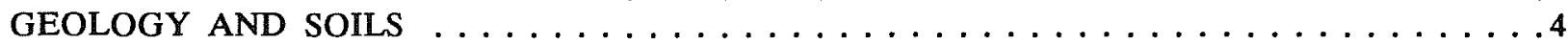

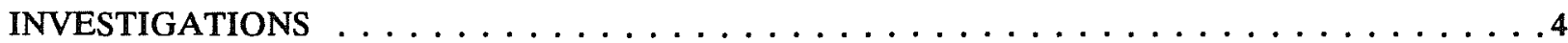

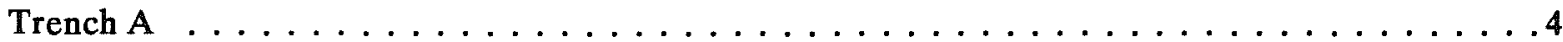

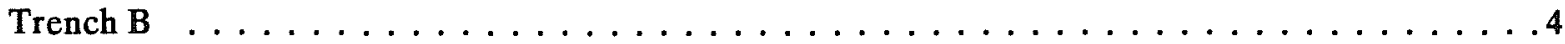

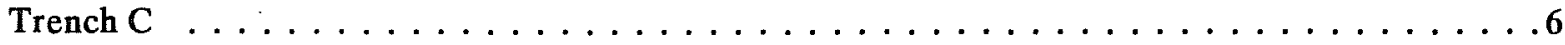

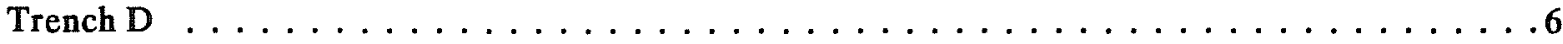

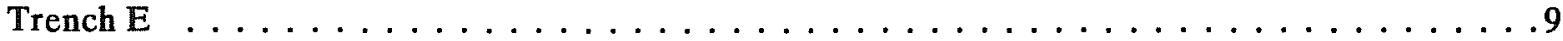

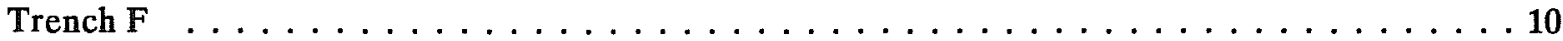

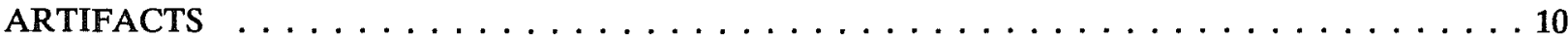

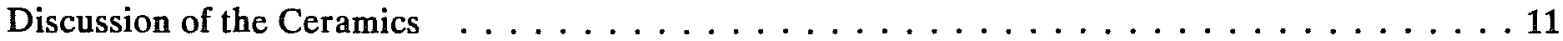

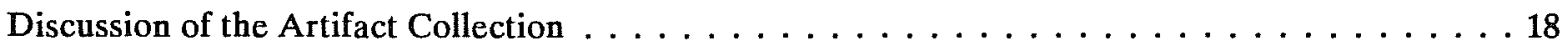

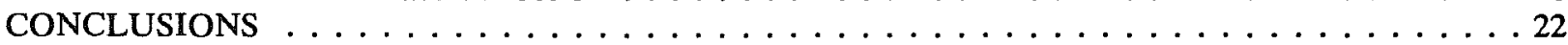

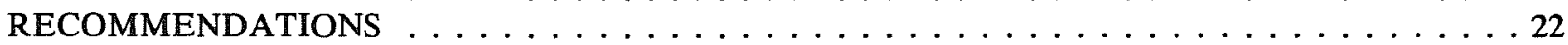

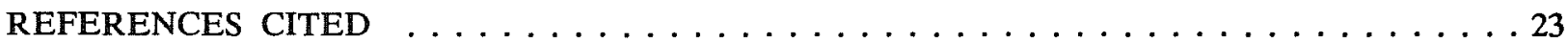

APPENDIX: ADDITIONAL TESTING (Maureen J. Brown) $\ldots \ldots \ldots \ldots \ldots \ldots \ldots \ldots$

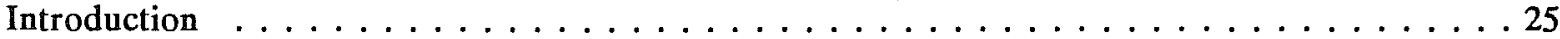

Artifacts Recovered During Testing at the Smith House . . . . . . . . . . . . . 25

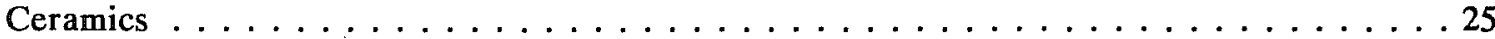

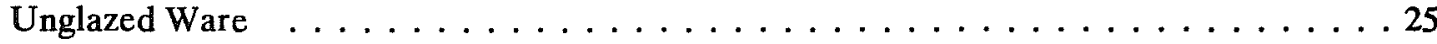

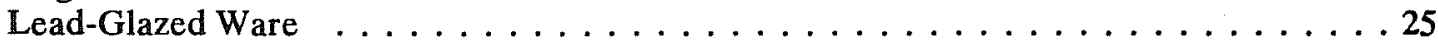

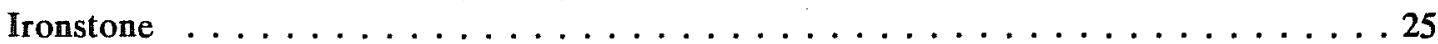

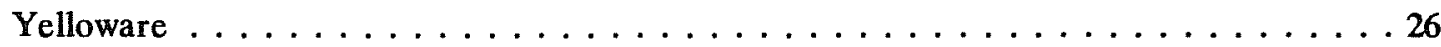

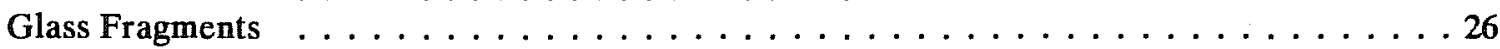

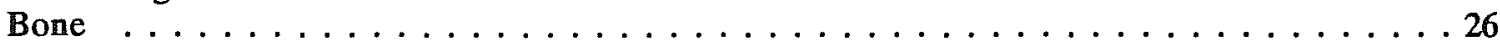

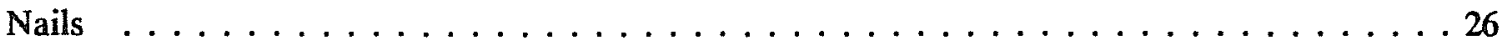

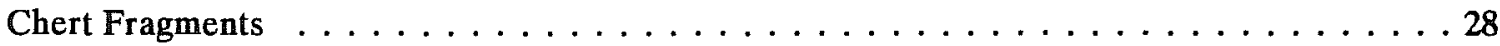

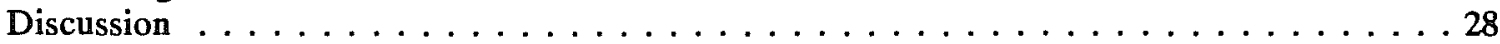

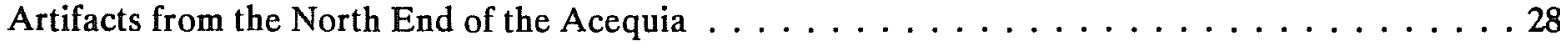

Ceramics . . . . . . . . . . . . . . . . . . . . . . 29

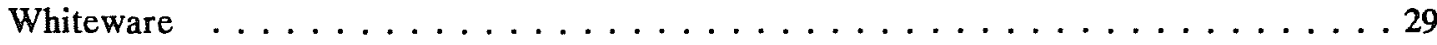

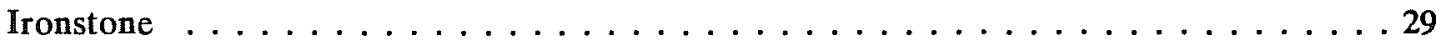

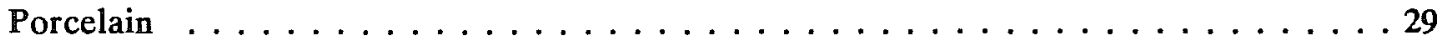

Stoneware . . . . . . . . . . . . . . . . . . . . 29

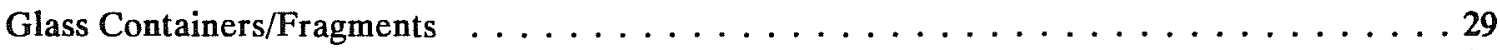

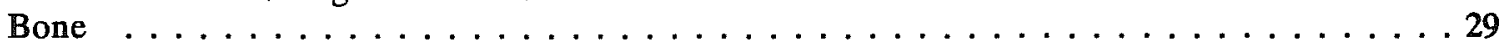

Metal . . . . . . . . . . . . . . . . . . . . . . . . 29

Chert Fragments . . . . . . . . . . . . . . . . . . . . . . 29

Discussion . . . . . . . . . . . . . . . . . . . . . 29

Conclusions . . . . . . . . . . . . . . . . . . . . . . . . . . 29

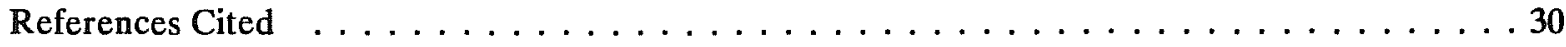





\section{LIST OF FIGURES}

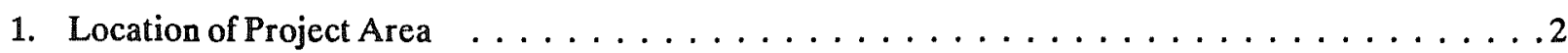

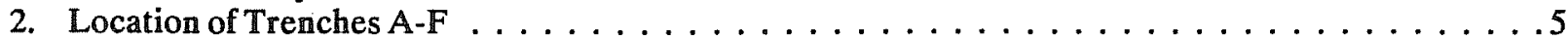

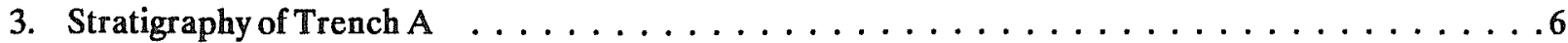

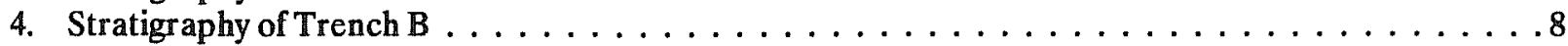

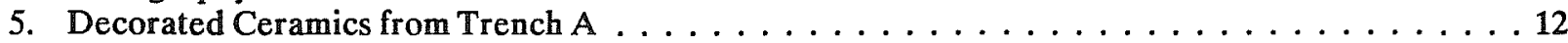

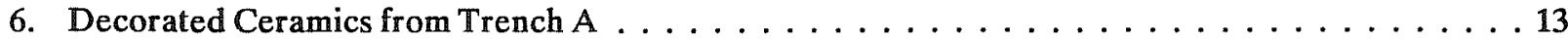

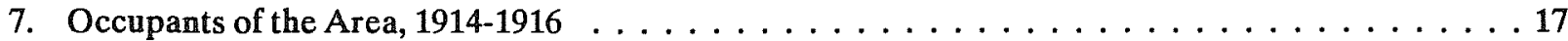

8. Typical Bottles from the Test Excavations . . . . . . . . . . . . . . . . . . 19

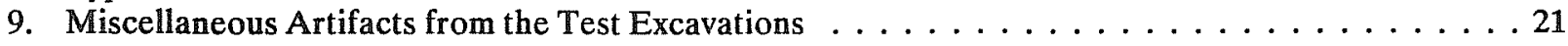

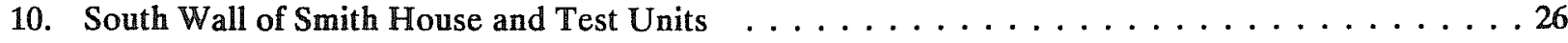

\section{LIST OF TABLES}

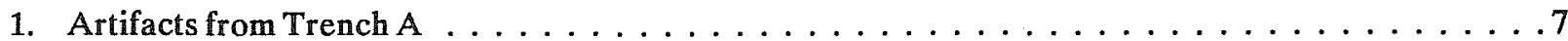

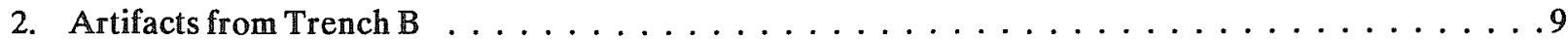

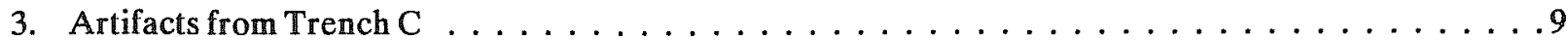

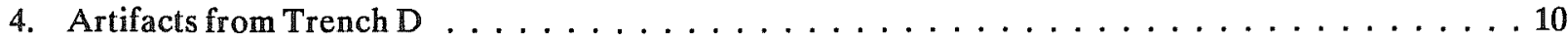

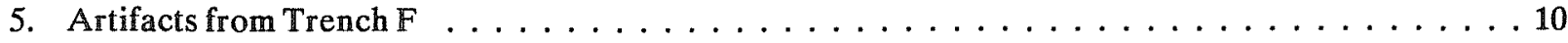

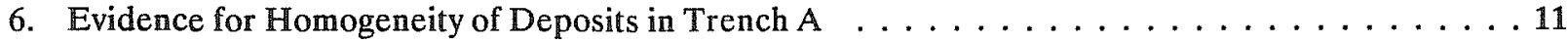

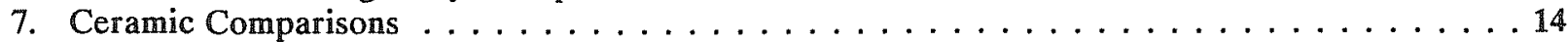

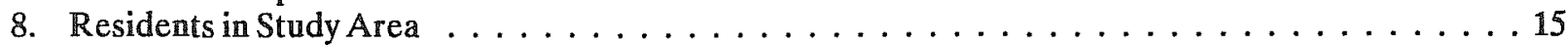

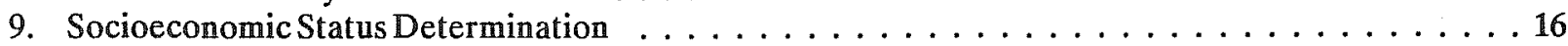

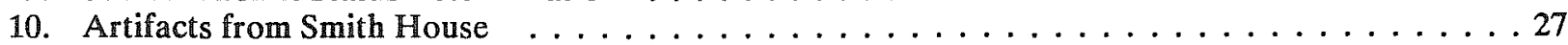

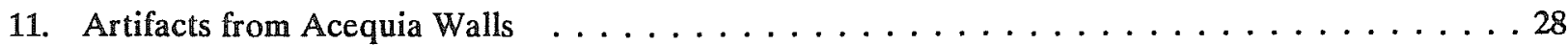





\section{ACKNOWLEDGMENTS}

A number of people are due thanks for assisting in the accomplishment of this project. John Cordner and Nathan Jones, project managers for Day \& Zimmerman, Inc., assisted in every way possible. We enjoyed working with David Bomersbach of Rehler, Vaughn, Beaty \& Koone, Inc., architects. As so often in the past, the success of the work depended to a great extent on the skillful operation of the backhoe by Mike Fulgham of Wrightway Backhoe. The volunteers who cheerfully contributed their time and talents to the project include Darla Cox, Deborah Ellis, Warren Miller, Carol Shoffner, Burnley Smith, and Tommy Tomesal. The whiteware pitcher for the cover of this report was photographed by Maureen Brown, and Frances Meskill completed the drafting of the cover design. Frances Meskill also drafted the illustrations within this report. 



\section{INTRODUCTION}

In August 1988, the Center for Archaeological Research (CAR) was requested by Day \& Zimmerman, Inc., project coordinators for the HemisFair remodeling project, to submit a proposal to monitor removal of two buildings and do test excavations in the southwest area of HemisFair Plaza in order to locate the route of the Alamo Acequia Madre (Fig. 1), determine its present condition, and sample its contents in various locations through the area. The work was to be done in preparation for drawing plans to restore the acequia within a proposed park. The CAR then entered into a contract with the City of San Antonio to do the work.

Four phases of archaeological and historical research have been completed in preparation for extensive development and renovation work planned for HemisFair Plaza. The first phase was a literature and archival study (Cox and Fox 1983). The second phase was a preliminary attempt to locate the acequia and determine its condition (Fox 1985). The third phase of work was monitoring of the various aspects of park construction by CAR personnel over the past two years, and the fourth phase is the present project reported here. The work has been done under Texas Antiquities Committee Permit No. 732 and in accordance with the guidelines set forth by the Council of Texas Archeologists (CTA 1981).

The project was conducted under the general supervision of Jack D. Eaton, acting director of the CAR, as principal investigator. Anne A. Fox served as coprincipal investigator and field director, and crew chief was I. Waynne Cox, a research associate with the CAR. Crew members were Kenneth Brown, Curt Harrell, and Clint McKenzie, members of the CAR staff. A total of 28 man-days was expended on the field work between January 3 and 9,1989 , nine of these days being contributed by volunteer avocational archaeologists. In addition, Fox and Cox spent the equivalent of several days monitoring a building and slab removal. Additional testing was later done around the Smith house, and a backhoe was monitored in the northern end of the acequia (see appendix for a report of this work). All notes, drawings, photographs, and artifacts are curated at the CAR laboratory.

\section{HISTORIC BACKGROUND}

The Acequia Madre, or main ditch, was constructed in the 1720s as an open, unlined ditch to carry water from the San Antonio River to irrigate the fields of Mission San Antonio de Valero. Leaving the river in Brackenridge Park, the acequia ran east of the mission, briefly dividing into an east and a west branch, then south through the lower mission fields where it joined into one stream just north of the project area and returned to the river in the King William area. The parts of the ditch that ran through the developed section of town were lined with cut stone in the mid-19th century (Cox 1985:2).

The project area was originally part of the lower fields or labor de abajo of Mission Valero. When the mission was secularized in 1793 , the area was subdivided and granted to local families (Habig 1968:66). The land was further subdivided in the late 19th century into individual building lots and became primarily a residential area. At some point at the turn of the century, the western branch of the acequia no longer contained water, although the eastern branch was not officially closed until ca. 1916 (Cox and Fox 1983:15). Once the water ceased to run in the ditches, they became a health hazard as rainwater and trash collected there. The neighboring residents began to complain until finally the city ordered all ditches to be filled. Apparently the most efficient way to accomplish this was to use the family trash, and dumping into the acequias became a popular way to fill them. This appears to have been done in rather rapid fashion, since acequia deposits excavated in various locations around the city seem to be unstratified (see Frkuska 1981; Cox 1985, 1986; and Fox et al. 1989).

The neighborhood gradually declined, and the old houses one by one became rental property as the original owners died or moved away. Some of the residences along South Alamo Street, the main artery through the area, were converted to commercial uses.

In 1964, the City of San Antonio began planning for HemisFair 1968 (Cox and Fox 1983:2), an international exposition to be located to the east of South Alamo Street, with Goliad Road as its main axis. Attention was focused for the first time on the number of important historic homes in the area. After much discussion and controversy, it was decided to preserve a group of buildings in the study area at the southwest corner of the fairgrounds to be used for various purposes during HemisFair. Among these were the Eagar home (434 South Alamo Street), the Perieda home (502 South Alamo Street), the Samuel Smith home (see appendix) at the corner of Goliad Road and Water Street (Cox and Fox 1983:13), and the houses at 529 and 533 Water Street. All of the intervening houses were demolished and removed, and a large concrete 


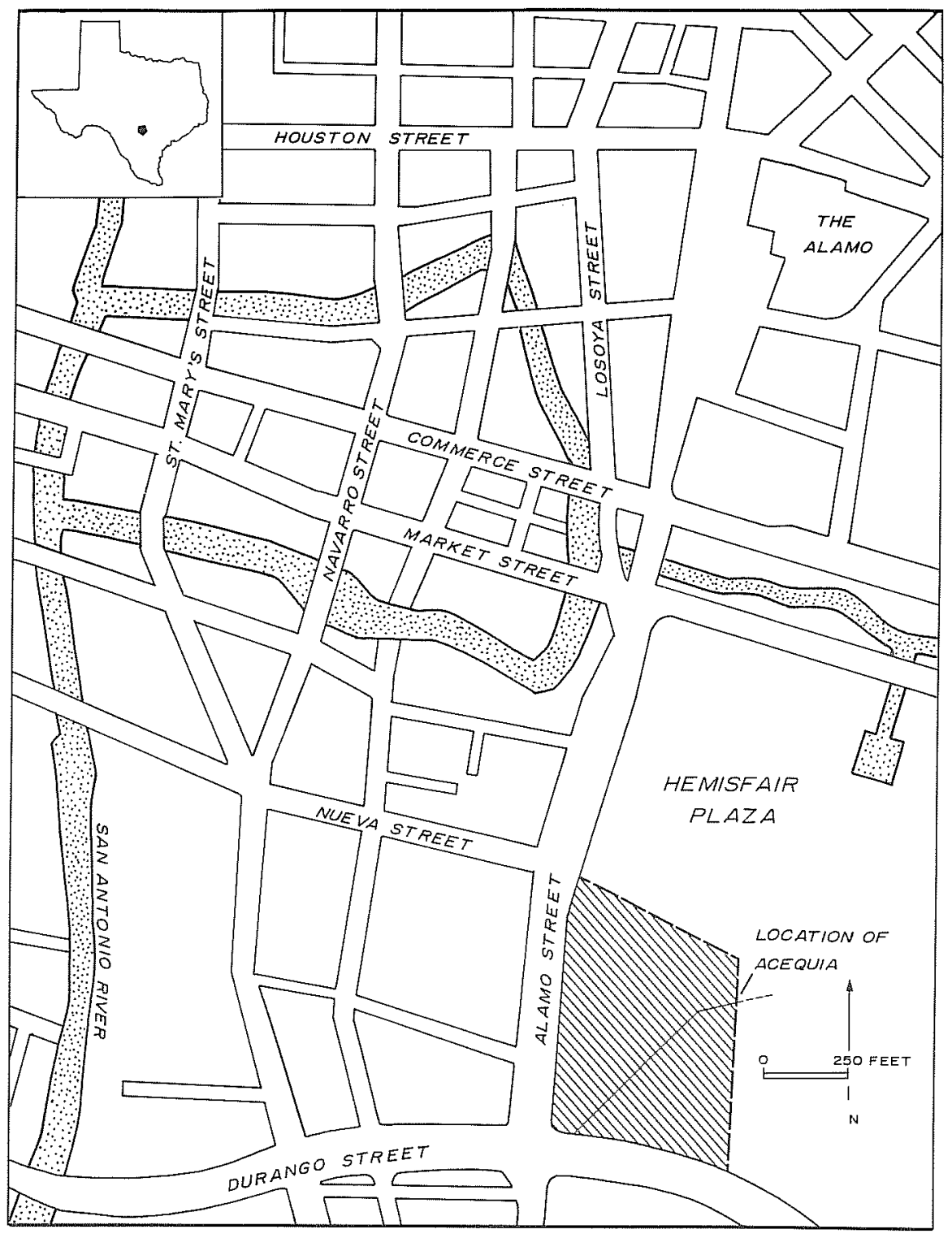

Figure 1. Location of Project Area. 
slab to support the Spanish Pavilion for the fair was poured over the acequia area, extending also over the site of the Dewees house (Cox and Fox 1983:Fig. 1).

After HemisFair, the Spanish Pavilion remained in place until the initiation of this project. It had a number of intermediary uses, the most well-known was as a Transportation Museum for the San Antonio Museum Association.

\section{PREVIOUS INVESTIGATIONS}

The CAR has conducted a number of archaeological investigations in the general vicinity of HemisFair Plaza. Directly across Alamo Street, in 1976, test excavations were conducted at house sites in the Arciniega Street area (Katz 1978). On the corner of Alamo Street and Nueva Street in the same general neighborhood, while testing for the relocation of the Fairmount Hotel in 1985, excavations were carried out at the site of an earthworks related to Gen. Santa Anna's forces at the battle of the Alamo (Labadie 1986). Directly west of that site, in 1978, test excavations were carried out at the Dolores Aldrete house (Fox, Valdez, and Bobbitt 1978).

On the HemisFair site itself, the first archaeological investigations were carried out in 1966 by the Witte Museum (Schuetz 1970) in preparation for the HemisFair development. This took place in a section of the Alamo Acequia Madre just north of the present project. The purpose of the excavations was to clean out a section of the acequia for use as a water feature in the patio of the Spanish Pavilion. The artifacts and field notes from this excavation are now curated at the CAR laboratory. As mentioned before, in 1983-1984, the CAR conducted test excavations to locate the route of the acequia to the south of the Witte Museum project. The result of this work indicated that the route of the acequia was farther to the east in the southern part of the area than at first estimated, and that, at least in one section, the west wall appeared to have been partially demolished and/or removed (Fox 1985:Fig. 4). In addition, the ditch was apparently used later for deposition of household trash.

The acequia, in the section excavated by Schuetz (1970:5), was found to be 6.3 feet wide, and the bottom was 5.2 feet below the ground surface at that time. The walls were lined with quarried limestone blocks varying in thickness from 10 to 14 inches and in length from 11 to 41 inches. Part of the top course of stone was missing from the walls, and some damage had been done to the east wall, leaving only two courses of stone in one section. At the time of the 1966 excavations, sections of the east wall of the ditch were visible on the ground surface to the south of the area under investigation (Fox, personal observation).

\section{RESEARCH DESIGN}

As mentioned briefly, the purpose of this project was to discover the location and condition of the acequia and to test its contents in order to allow a determination of whether additional archaeology would be necessary before the actual reconstruction began. Since there was some difficulty in locating the acequia during Phase II investigations, owing to the absence of the west wall and the depth of fill in the area, the decision was made to proceed from the known portion at the north end of the area with regularly placed trenches, determining in each case where the channel lay before opening the next one. The use of a backhoe has been found to be an economical and comparatively nondestructive method of excavation when done with previous knowledge of the ground fill stratification in the area. It is necessary, however, to have an experienced backhoe operator, preferably one who has worked with archaeologists and is sensitive to their concerns.

The decision was made to excavate double wide trenches, that is using two parallel cuts of the backhoe bucket, resulting in a four-foot-wide trench. The reason for this lay in the comparative instability of the upper layer of gravel, and the probable necessity of excavating to five feet or slightly more in order to reveal the condition of the acequia.

Several research questions were formulated which the project methodology was designed to answer, in addition to the obvious questions about the location and condition of the acequia.

1. Was the acequia filled gradually over a period of time, or all at once in a single operation?

2. Are there differences in the fill of the acequia at different locations that could be attributed to the socioeconomic status of the households contributing to it?

3. If such differences exist, how can they be determined, measured, and explained?

The previous excavation of a section of the acequia directly north of the area to be investigated yielded an interesting collection of artifacts (Schuetz 1970:7-13) which are curated at the CAR laboratory and thus were conveniently available for comparison. In order to obtain data that would 
answer the research questions, it was necessary to obtain a carefully controlled sample at a distance sufficiently removed from the Schuetz excavation to guarantee that a different set of households could be contributing to the fill. The location and treatment of Trench $A$ in the current tests were designed to provide the necessary data.

\section{METHODOLOGY}

Measuring from the south end of the exposed section of the acequia that had been restored for HemisFair, a series of test trenches was laid out across the estimated location of the acequia, based on the results of the testing in 1983-1984 (Fox 1985:Fig. 3). A backhoe with a two-foot bucket was used to excavate these trenches, starting with the northernmost one nearest the open section, following the line of the ditch as it was revealed. The backhoe removed the upper layers of HemisFair fill, which consisted mostly of gravel brought in as a base for the concrete slabs that held the buildings, until the first sign of the cut stone lining of the acequia appeared. Excavation below this level was primarily done by hand, with screening done through $1 / 4$-inch mesh in selected areas to test the trash content of the acequia fill.

The first trench, Trench A, was completely excavated by hand from the level of the top of the stone lining on the east wall, in one-foot levels, with all soil screened through $1 / 4$-inch screens, until the bottom of the wall and, therefore, the bottom of the acequia was reached. This was done in order to obtain a complete sample to test for dating of deposition, and to compare with the materials recovered by Schuetz in 1966. The contents of the other successive trenches were sampled in various ways which are described later.

\section{GEOLOGY AND SOILS}

The site is located on a relatively flat terrace above the San Antonio River. The present surface has a slope of about 1.09 feet from the north to the south end of the area in question. Soils in the general area are Venus-Frio-Trinity association soils (Taylor, Hailey, and Richmond 1966). These are grayish brown alluvial soils that occur throughout the river valley in bottomlands and terraces.

\section{INVESTIGATIONS}

After the demolition of the two buildings (Building 201 and Buildings 236-245) originally constructed for use during HemisFair, the removal of the concrete slabs that supported them was monitored by the archaeologists to make sure that the acequia was not damaged in the process. The demolition contractor was careful to remove only the concrete slabs and supporting grade beams, leaving in place the gravel base upon which they were constructed. Trenches A-F were then excavated along the route of the acequia (Fig. 2).

\section{TRENCH A}

Trench A was laid out perpendicular to the centerline of the acequia as observed in the section restored for HemisFair. The backhoe excavated an area ca. 4 feet $x 16$ feet to a depth of ca. 2.5 feet (Fig. 3 ), removing Zone I, pale brown caliche and gravels; Zone II, whitish caliche and angular gravels; Zone III, dark gray clay; and the top portion of Zone IV, loose gray clay containing ceramic sherds, glass fragments, bone fragments, and other household artifacts (Table 1). The upper portion of this level contained numerous fragments of ceramic sewer tile, and large limestone rocks were present throughout. Hand excavation and screening were then begun. An area the width of the acequia plus the width of the west wall ( 6.5 feet) was laid out for excavation within the ditch to the west of the east wall. A datum was established on the top of the east wall, and one-foot levels were excavated to the bottom of the acequia at ca. 6 feet below the present ground surface.

\section{TRENCH B}

Trench B was parallel to Trench $A$ on a line with the location of the acequia as observed in that trench. It measured ca. 4 feet $\times 15$ feet. The backhoe removed the overburden of gravels until the top of the east wall and the top of a concrete base containing vertical reinforcing rods were revealed. The top of the wall was found at 2.02 feet below the present surface (Fig. 4), the pylon base at 1.75 feet. A search with the backhoe to the west of the concrete foundation to a depth of 6 feet failed to find a definite west wall for the acequia, although limestone rubble was present in the floor of the excavation at the approximate location of the wall (ca. 6.5 feet west of the east wall). A sample of the artifacts was recovered (Table 2). 


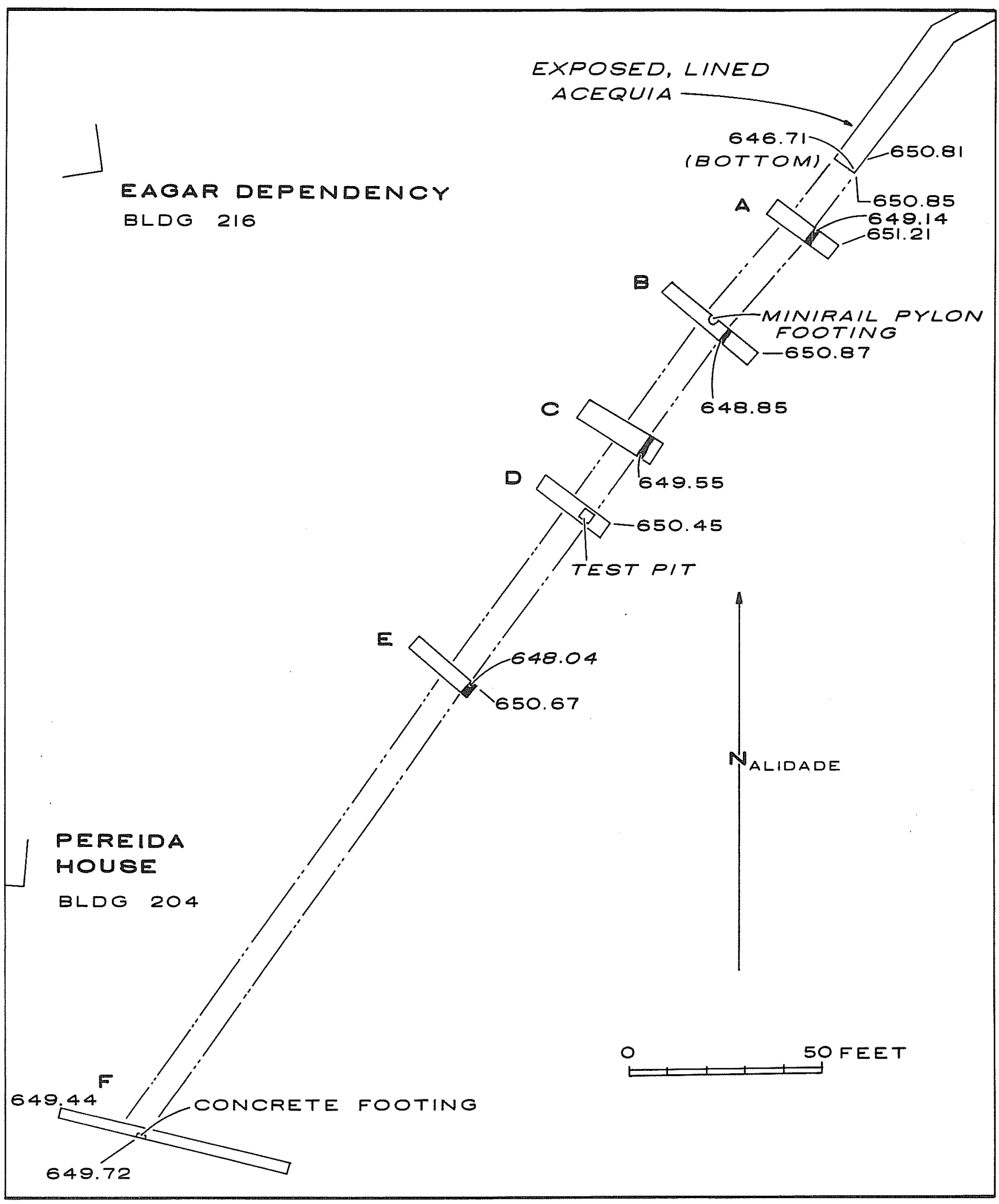

Figure 2. Location of Trenches $A-F$. 


\section{PROFILE OF TRENCH A, LOOKING SOUTH}

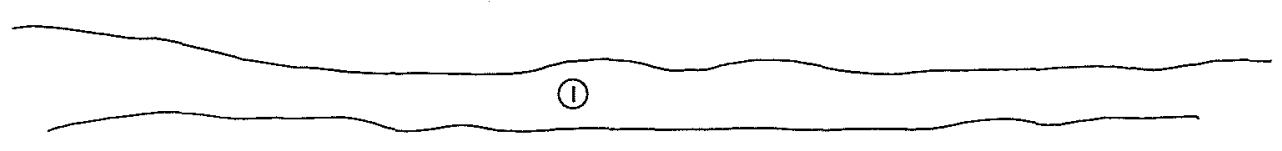

(2)

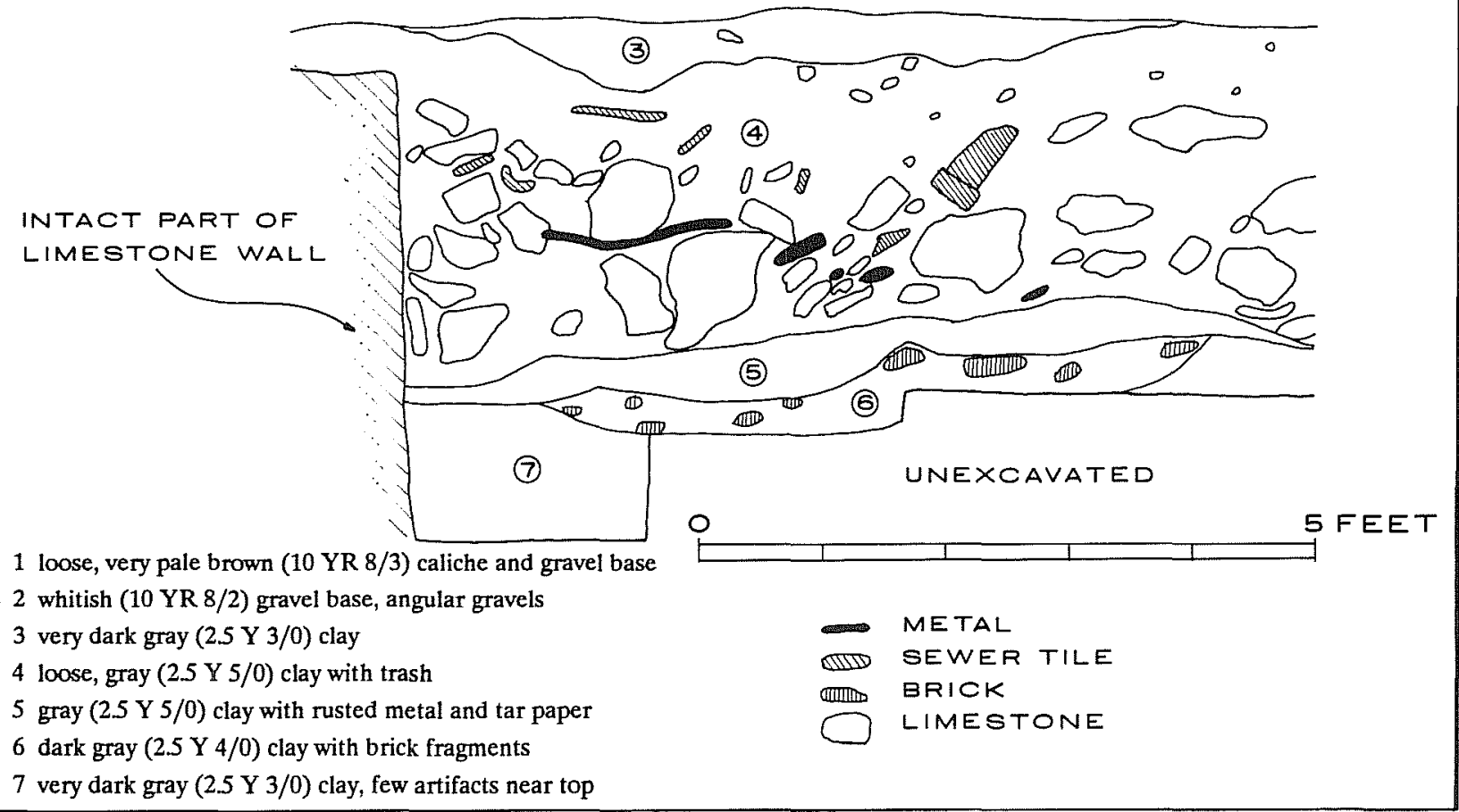

Figure 3. Stratigraphy of Trench $A$.

\section{TRENCH C}

Trench C, ca. 5 feet $\times 20.3$ feet, was excavated, to the south of Trench B. The top of the acequia's east wall was found at 1.09 feet below the surface. Directly west of the wall were found layers of demolition debris and household trash, including mattress springs and the remains of the metal frame from a baby carriage. There was no sign of the west wall when the excavations ceased at a depth of 5 feet, although the character and hardness of the soil changed at approximately 7 feet west of the east wall. A sample of the artifacts was recovered (Table 3) for comparison with those from the other trenches.

\section{TRENCH D}

Trench $D$, south of Trench $C$ and outside the wall line of the Spanish Pavilion constructed over the acequia for HemisFair, revealed stratification identical to that found in the test trench excavated in 1983 (Fox 1985:Fig. 4, Trench 2). Beneath the gravels, a tan sandy loam overlay a stratum of dark brown soil filled with small, rounded gravels sitting on a layer of black polyethylene, evidently installed for HemisFair. Beneath this were layers of tan sand, gray clay, dark brown clay, and caliche which capped the trash deposits within the acequia. Although the stratification was not apparent during excavation, the outline of the sunken top of the acequia deposits capped by these layers was evident 
TABLE 1. ARTIFACTS FROM TRENCH A

\begin{tabular}{|c|c|c|c|}
\hline ARTIFACT TYPE & $\begin{array}{l}\text { NUMBER OF } \\
\text { SPECIMENS }\end{array}$ & ARTIFACT TYPE & $\begin{array}{l}\text { NUMBER OF } \\
\text { SPECIMENS }\end{array}$ \\
\hline 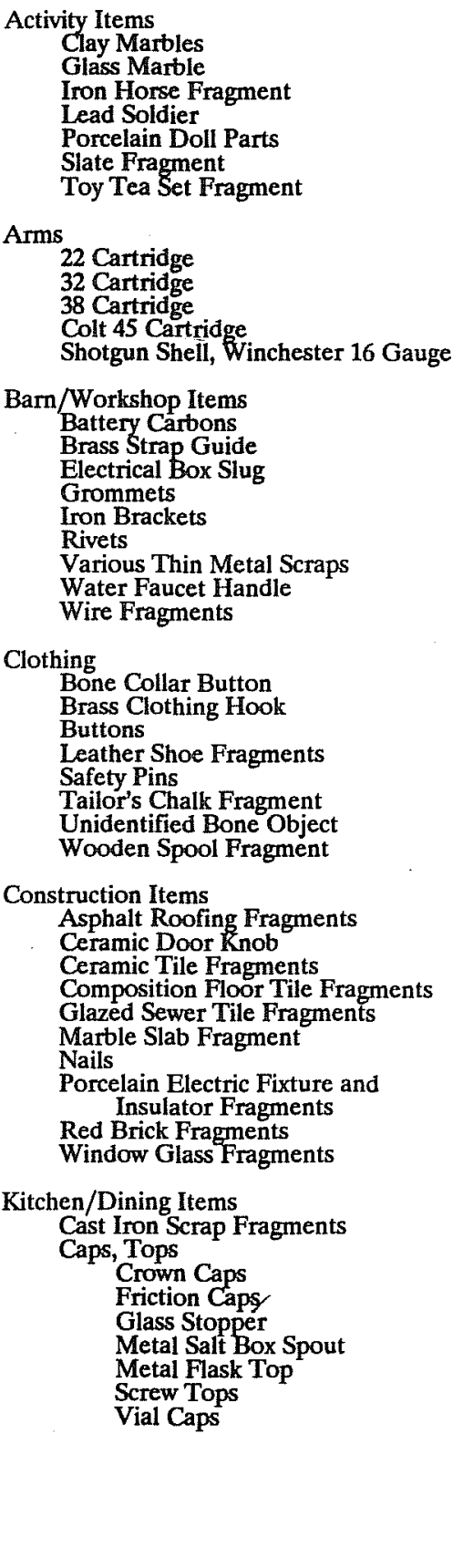 & $\begin{array}{r}3 \\
1 \\
5 \\
9 \\
5 \\
1 \\
837 \\
\\
15 \\
9 \\
61\end{array}$ & $\begin{array}{l}\text { Ceramic Sherds } \\
\text { Brazier } \\
\text { Burnished Slipware } \\
\text { Decal Decorated Whiteware } \\
\text { Decal on Porcelain } \\
\text { Flower Pot Fragments } \\
\text { Flown Blue on Whiteware } \\
\text { Galera Ware } \\
\text { Gold on Porcelain } \\
\text { Hand Painted (two under glaze) } \\
\text { Painted Porcelain } \\
\text { Red Stoneware with White Glaze } \\
\text { Silver Luster On Porcelain } \\
\text { Silver or Gold on Whiteware } \\
\text { Solid Color Glaze } \\
\text { Stoneware } \\
\text { Stoneware Bottle } \\
\text { Tin Glazed } \\
\text { Transfer on Whiteware } \\
\text { Undecorated Porcelain } \\
\text { Undecorated Whiteware } \\
\text { (19 molded) } \\
\text { Yelloware } \\
\text { Food Items } \\
\text { Animal Bone Fragments } \\
\text { Egg Shell Fragments } \\
\text { Peach Pits } \\
\text { Glass Container Fragments } \\
\text { Aqua } \\
\text { Blue } \\
\text { Brown } \\
\text { Clear } \\
\text { Green } \\
\text { White } \\
\text { Yellow } \\
\text { Kitchenware } \\
\text { Enameled Pan Handles } \\
\text { Tableware } \\
\text { Silver Spoon Bow } \\
\text { Stainless Steel Knife } \\
\text { Thin Tin Cup Scrap } \\
\text { Household Furnishings } \\
\text { Boss for Drawer Pull } \\
\text { Cabinet Door Hinge } \\
\text { Cabinet latch } \\
\text { Clock Parts } \\
\text { Clothes Hooks } \\
\text { Clothes Pin Spring } \\
\text { Copper Tacks } \\
\text { Light Bulb Parts } \\
\text { Key } \\
\text { Pull Knob } \\
\text { Unidentified Metal Fastener } \\
\text { Personal Items } \\
\text { Brass Tag } \\
\text { Composition Comb Fragments } \\
\text { Garterbelt Hook } \\
\text { Glass Beads } \\
\text { Jewelry Fragments } \\
\text { Lincoln Penny 1946 } \\
\text { Metal Lipstick Tubes } \\
\text { Metal Purse Frame Fragments } \\
\text { Perfume Applicator Fragments } \\
\text { Smoking Pipe Fragment } \\
\text { 1 }\end{array}$ & $\begin{array}{r}2 \\
5 \\
85 \\
39 \\
9 \\
14 \\
12 \\
14 \\
10 \\
40 \\
3 \\
7 \\
20 \\
10 \\
71 \\
1 \\
3 \\
13 \\
40 \\
270 \\
1 \\
1000 \\
5 \\
3 \\
301 \\
30 \\
535 \\
2349 \\
234 \\
78 \\
63 \\
21 \\
2 \\
2 \\
1 \\
11 \\
243\end{array}$ \\
\hline
\end{tabular}




\section{PROFILE OF TRENCH B, LOOKING NORTH}

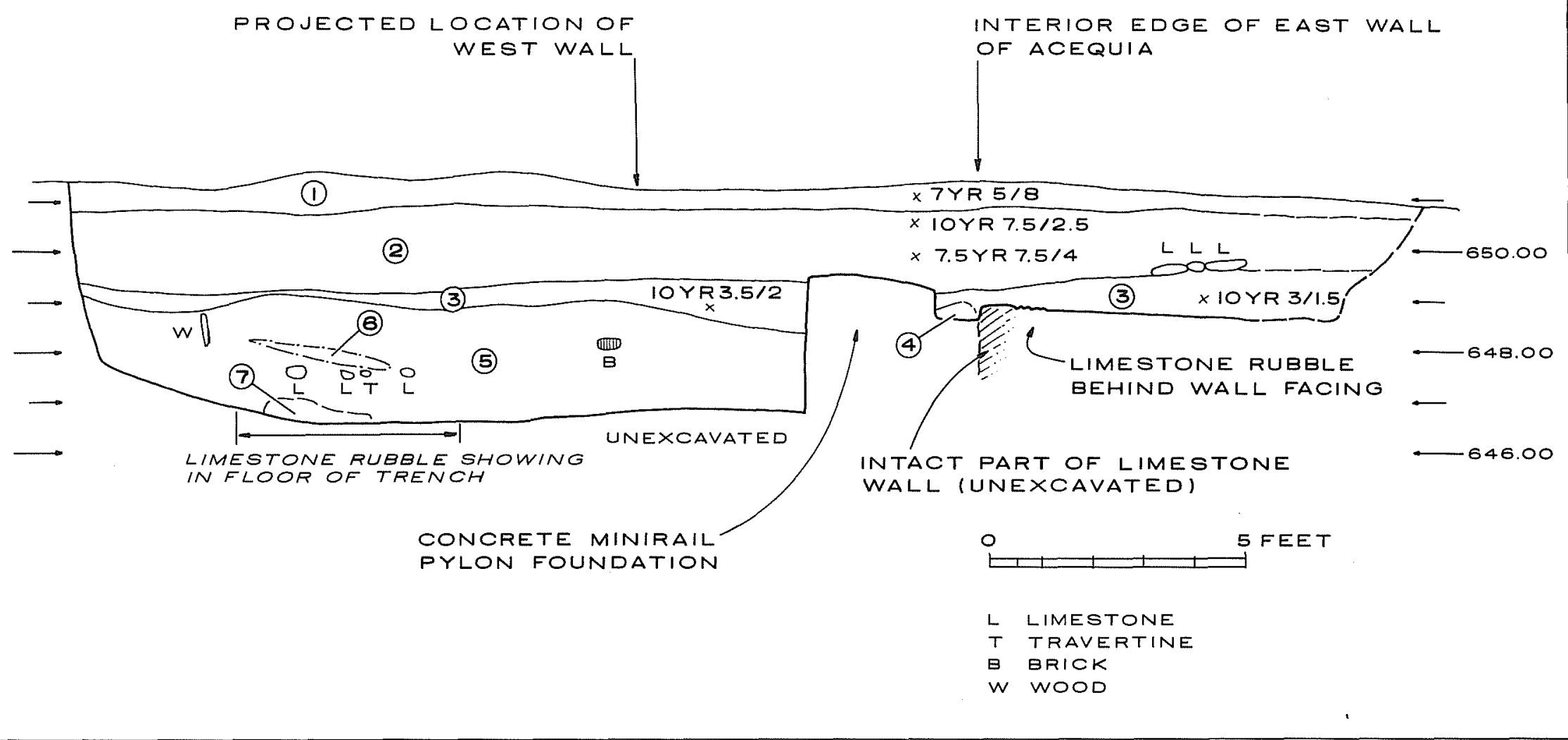

1 loose beige (7.5 YR 5/8), fine sandy clay and limestone gravel; fill introduced during HemisFair redevelopment project

2 light gray brown (10 YR 7.5/2.5 to 7.5 YR 7.5/4) fine sandy clay with abundant limestone gravel, occasional sewer tile and brick; lower half is less gray, has less clay and more rock (contact between these two subunits not drawn)

3 compact medium gray (10 YR 3.5/1.5-2) clay, marbled with cream-colored clay, caliche nodules; irregular lower boundary

4 caliche lens, probably of limited extent; homogeneous white (10 YR 9/2)

5 homogeneous dark gray, nearly sterile, very compact clay, nearly black when wet; color not recorded. Cultural debris is present but very uncommon.

6 granulated lime, origin unknown

7 limestone rubble, appearing more extensively in the floor than in the profile.

Figure 4. Stratigraphy of Trench $B$. 
TABLE 2. ARTIFACTS FROM TRENCH B

Household Furnishings

Ceramic Lamp Base Fragment

Kitchen/Dining Items

Glass Container Fragments

Aqua

Brown

2

Clear

Green

in the profile of the trench. When sherds of ceramics and glass began to appear, the machine excavation was stopped, and a controlled sample (Table 4) was taken by hand excavating and screening an area 4.75 feet $x 4$ feet in the bottom of the trench. No signs of east or west walls for the acequia were found, but the original location of the east wall could be estimated by plotting the intensity of the artifact deposits. Directly outside the line of the east wall were found two cedar posts, apparently the remains of a small outbuilding in the back yard of the adjacent house. Several such outbuildings are shown on various Sanborn Insurance Company maps for the area.

\section{TRENCH E}

Trench E, ca. 3.5 feet $\times 20$ feet, was excavated through the asphalt surface of the parking lot directly south on the acequia line as projected from the earlier units. The same stratification was found as in Trench D. The east wall was present, the top being 2.63 feet below the surface, and there was no sign of the west wall. No sample of the artifactual content of the acequia was recovered from this trench.

TABLE 3. ARTIFACTS FROM TRENCH C

\begin{tabular}{|c|c|c|c|}
\hline ARTTFACT TYPE & $\begin{array}{l}\text { NUMBER OF } \\
\text { SPECIMENS }\end{array}$ & ARTIFACT TYPE & $\begin{array}{l}\text { NUMBER OF } \\
\text { SPECIMENS }\end{array}$ \\
\hline $\begin{array}{l}\text { Activity Items } \\
\text { Metal Trolley Token } \\
\text { Toy Wheelbarrow } \\
\text { Construction Items } \\
\text { Ceramic Insulator } \\
\text { Concrete Fragment } \\
\text { Cut Nails } \\
\text { Plaster Fragments } \\
\text { Various Tile Fragments } \\
\text { Window Glass Fragments } \\
\text { Household Furnishings } \\
\text { Coat Hook } \\
\text { Porcelain Casters } \\
\text { Trunk Hardware Fragments }\end{array}$ & $\begin{array}{r}1 \\
1 \\
6 \\
8 \\
5 \\
19\end{array}$ & $\begin{array}{c}\text { Kitchen/Dining Items } \\
\text { Ceramic Sherds } \\
\text { Painted Overglaze } \\
\text { on Whiteware } \\
\text { Polychrome Transfer } \\
\text { on Whiteware } \\
\text { Stoneware } \\
\text { Undecorated Whiteware } \\
\text { Glass Container Fragments } \\
\text { Brown } \\
\text { Clear } \\
\text { Crown Bottle Cap } \\
\text { Tin Can Scrap }\end{array}$ & $\begin{array}{r}1 \\
1 \\
4 \\
14 \\
3 \\
14 \\
1 \\
3\end{array}$ \\
\hline
\end{tabular}




\section{TRENCH F}

Trench F, ca. 3.5 feet $x 20$ feet, was excavated on the location where Building 201 had stood, in line with the acequia as revealed in the preceding trenches. The concrete footings of the building had been large and deep, and the crew had not much hope of the acequia walls surviving the demolition and removal of the grade beams. However, at 2.63 feet below the surface, the top of the east wall was found. The general stratification below the gravel base for the building was similar to that in the other trenches. The acequia trash fill was covered with a layer of whitish tan, powdery caliche. There was no west wall present. A sample of the artifacts was recovered (Table 5).

\section{ARTIFACTS}

Tables 1 through 5 list the artifacts recovered from trench excavations. Considered as a whole, the artifacts represent an interesting cross section of the household goods available to the residents of San Antonio in the early 20th century. They also compare closely with the artifacts recovered by Schuetz in 1966, just upstream. However, the only cross-mending or matching between the collections is one ceramic ironstone sherd from Trench $D$ which cross-mends with a pitcher excavated by Schuetz. It is difficult to imagine how this one piece could have strayed so far from the original deposit (see Fig. 2), unless it was picked up and carried by someone during or soon after filling.

TABLE 4. ARTIFACTS FROM TRENCH D

\begin{tabular}{|c|c|c|c|}
\hline ARTIFACT TYPE & $\begin{array}{l}\text { NUMBER OF } \\
\text { SPECIMENS }\end{array}$ & ARTIFACT TYPE & $\begin{array}{l}\text { NUMBER OF } \\
\text { SPECIMENS }\end{array}$ \\
\hline $\begin{array}{l}\text { Barn/Workshop Items } \\
\text { Barrel Hoop Fragments } \\
\text { Wire Fragments } \\
\text { Clothing } \\
\text { Buckle } \\
\text { Leather Shoe Parts } \\
\text { Shell Button } \\
\text { Construction Items } \\
\text { Brick Fragment } \\
\text { Nails } \\
\text { Slate Fragment } \\
\text { Window Glass Fragments } \\
\text { Household Furnishings } \\
\text { Bracket } \\
\text { Flower Pot Fragment }\end{array}$ & $\begin{array}{r}1 \\
42 \\
1 \\
23\end{array}$ & $\begin{array}{c}\text { Kitchen/Dining Items } \\
\text { Bone Fragments } \\
\text { Ceramic Sherds } \\
\text { Painted on Whiteware } \\
\text { Porcelain } \\
\text { Stoneware } \\
\text { Transfer on Whiteware } \\
\text { Undecorated Whiteware } \\
\text { Glass Container Fragments } \\
\text { Aqua } \\
\text { "Black" } \\
\text { Brown } \\
\text { Clear } \\
\text { White } \\
\text { Tin Can Scrap } \\
\text { Personal Item } \\
\text { Bone Toothbrush Head }\end{array}$ & $\begin{array}{r}125 \\
1 \\
5 \\
23 \\
3 \\
13 \\
27 \\
1 \\
2 \\
39 \\
1 \\
1 \\
1\end{array}$ \\
\hline
\end{tabular}

TABLE 5. ARTIFACTS FROM TRENCH F

\begin{tabular}{|c|c|c|c|}
\hline ARTIFACT TYPE & $\begin{array}{l}\text { NUMBER OF } \\
\text { SPECIMENS }\end{array}$ & ARTIFACT TYPE & $\begin{array}{l}\text { NUMBER OF } \\
\text { SPECIMENS }\end{array}$ \\
\hline $\begin{array}{l}\text { Activity Items } \\
\text { Porcelain Doll Leg } \\
\text { Clothing } \\
\text { Shell Button } \\
\text { Construction Items } \\
\text { Window Glass Fragments } \\
\text { Kitchen/Dining Items } \\
\text { Bone Fragments }\end{array}$ & 1 & $\begin{array}{l}\text { Ceramic Sherds } \\
\text { Flown Blue on Whiteware } \\
\text { Porcelain } \\
\text { Stoneware } \\
\text { Undecorated Whiteware } \\
\text { Yelloware } \\
\text { Glass Container Fragments } \\
\text { Aqua } \\
\text { "Black" } \\
\text { Brown } \\
\text { Clear } \\
\text { Green }\end{array}$ & $\begin{array}{r}1 \\
5 \\
13 \\
15 \\
7 \\
7 \\
7 \\
3 \\
8 \\
7 \\
4\end{array}$ \\
\hline
\end{tabular}




\section{DISCUSSION OF THE CERAMICS}

A representative sample of the decorated ceramics recovered from Trench A is illustrated in Figures 5 and 6 . The principle method of decoration is decalcomania, and the preferred colors are pastel shades of pink, blue, and green. Delicate decal or transfer designs accented or outlined with gold or silver appear to be the most fashionable pattern statement (Figs. 5,a, d, e, h, i; $6, b, c, d)$. Decal decoration is also found on whiteware (Figs. 5,b; 6,a) of this period. Solid color glazes on whiteware were just coming into use; an example is a yellow-glazed sherd with blue rim band (Fig. 5,c). Transfer patterns unique to the turn of the century and after were sometimes applied overglaze (Fig. 5,f). One sherd from a delicate porcelain teacup (Fig. $5, \mathrm{~g}$ ) that may have been a family heirloom bears flown blue decoration. All maker's marks identified on these ceramics indicate that they were imported from British or European factories.

Ceramics are particularly useful in analysis of artifacts from a site, since they can be dated with some degree of certainty, and the various types can also be used to draw tentative conclusions about the comparative life style of the household represented. Analysis of the provenience of cross-mended and matching sherds from Trench A (Table 6) demonstrates that the artifacts were all deposited in the ditch in one operation, rather than over a period of time, probably after the ditch no longer carried water and was purposely filled. The exact date has yet to be established from historic records. A similar method of deposition was observed in the section excavated by Schuetz, as well as in other acequia projects in San Antonio.

Miller (1980:4) has divided white-bodied ceramics of the early 19th century into categories depending upon the type of decoration used, in order to estimate their original cost. He has discovered that the price of the ware was determined by the amount of effort required to produce it, making undecorated wares the least expensive and transfer-printed ware the most expensive. Miller's categories can be carried forward, to a degree, up to and past 1900 by equating decalcomania decoration with transfer printing (Henry 1987:368). In general, throughout this time, porcelain has been the most expensive ware available (Miller 1980:4), although Henry (1987:369) observed that by the time the 1927 Sears Roebuck catalog was issued, German porcelain had become less expensive than English decal-decorated whitewares. Porcelain was still, however, more expensive than plain, undecorated whitewares.

TABLE 6. EVIDENCE FOR HOMOGENEITY OF DEPOSITS IN TRENCH A

Cross-Matching Sherds

Stoneware with Bristol glaze

Whiteware with flown blue

Whiteware with flown blue

Whiteware with repoussé

Whiteware with blue rim and floral decal

Flower pot

Porcelain with floral decal

Whiteware with bluebird decal

Whiteware with floral decal

Porcelain with decal

Porcelain

Matching Patterns

Porcelain with blue rim, gold line

Whiteware with flown blue

Stoneware with blue and green sponge
Trench A, Level 1 and Trench A, Level 3

Trench A, Level 1 and Trench A, Level 2

Trench A, Level 1 and Trench A, Level 3

Trench A, Level 1 and Trench A, Level 3

Trench A, Level 1 and Trench A, Level 2

Trench A, Level 2 and Trench A, Level 3

Trench A, Level 1 and Trench A, Level 2

Trench A, Level 1 and Trench A, Level 2

Trench A, Level 1 and Trench A, Level 2

Trench A, Level 1 and Trench A, Level 2

Trench A, Level 1 and Trench A, Level 2

Trench A, Level 1 and Trench A, Level 2 Trench A, Level 1 and Trench A, Level 2 Trench A, Level 1, Trench A, Level 2, and Trench A, Level 3 


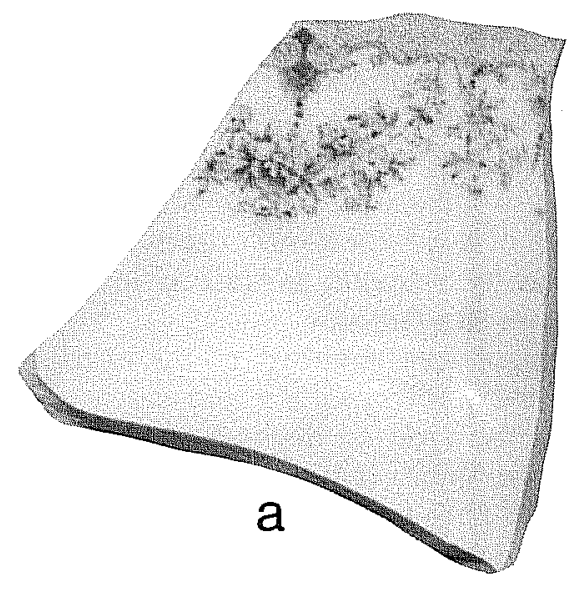

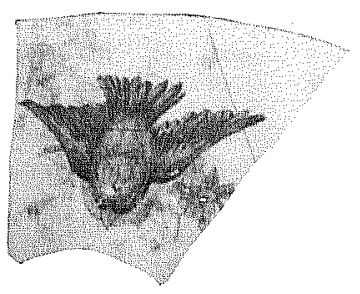

b

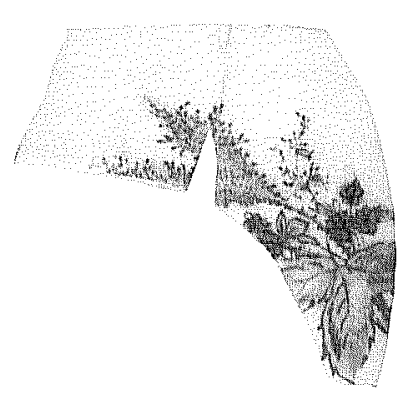

e

n

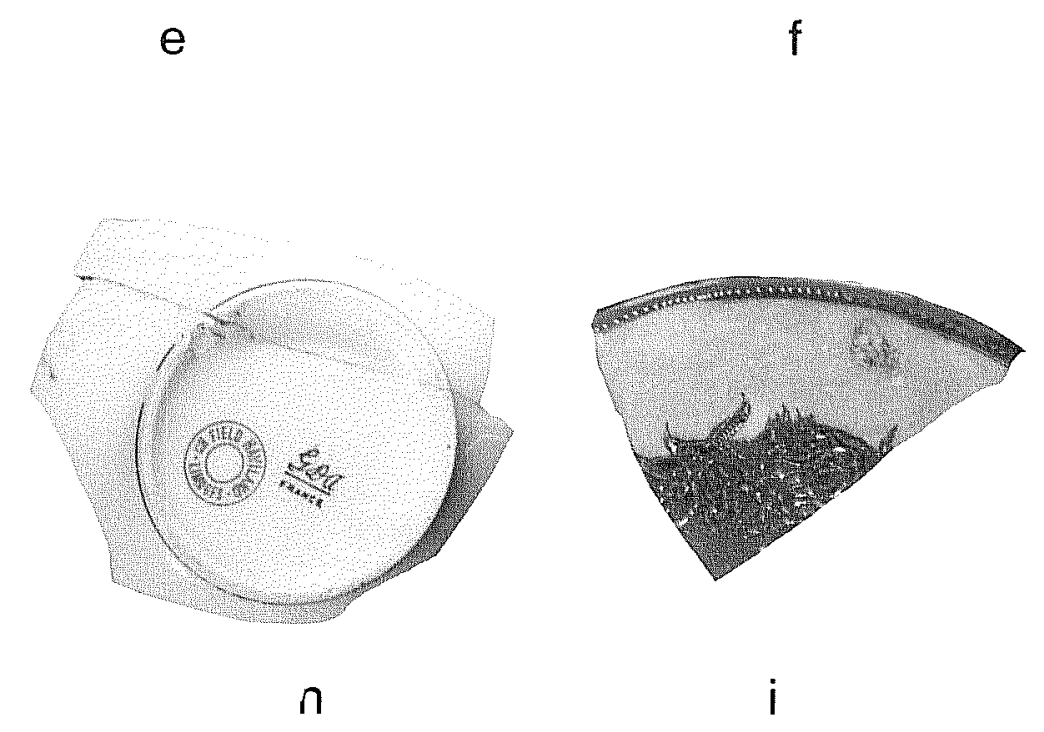

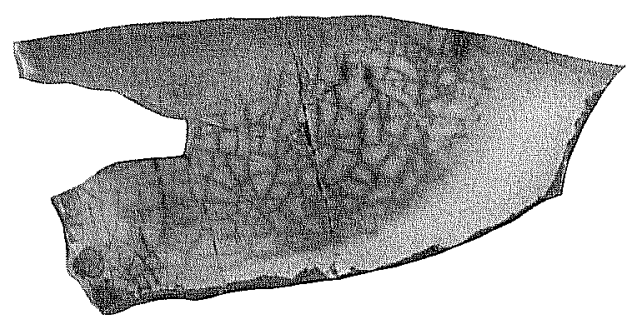

C

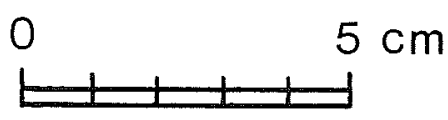

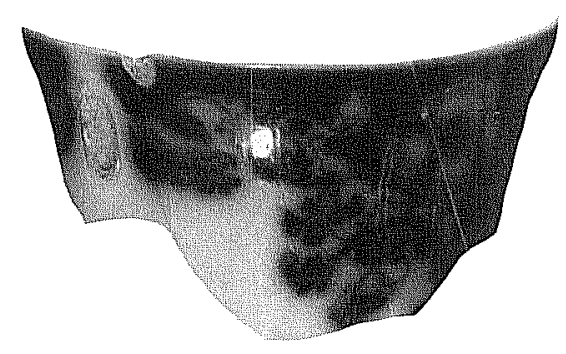

g

Figure 5. Decorated Ceramics from Trench $A$. a, blue transfer with gold highlighting overglaze ironstone serving dish fragment, Trench A, Level 2; b, bluebird pink and green decal, blue rim whiteware cup fragment, Trench A, Level 1-2; c, yellow glaze, blue rim whiteware bowl sherd, Trench A, Level 1; d, pink and green decal, silver luster porcelain cup sherd, Trench A, Level 1; e, brown, blue, and green decal, gold band porcelain cup sherd, Trench A, Level 1-2; f, blue transfer porcelain saucer sherd, Trench A, Level 1-2; g, flown blue porcelain cup sherd, Trench $A$, Level $1 ; \mathrm{h}$, gold band porcelain cup sherd with the inscription, "C H FIELD/HAVILAND/LIMOGES/GDA/FRANCE" Charles Field Haviland Company, 1842-1898 (Kovel and Kovel 1971:167,k, 51,m), Trench A, Level 1; i, gold decoration porcelain lid sherd, Trench A, Level 1. 

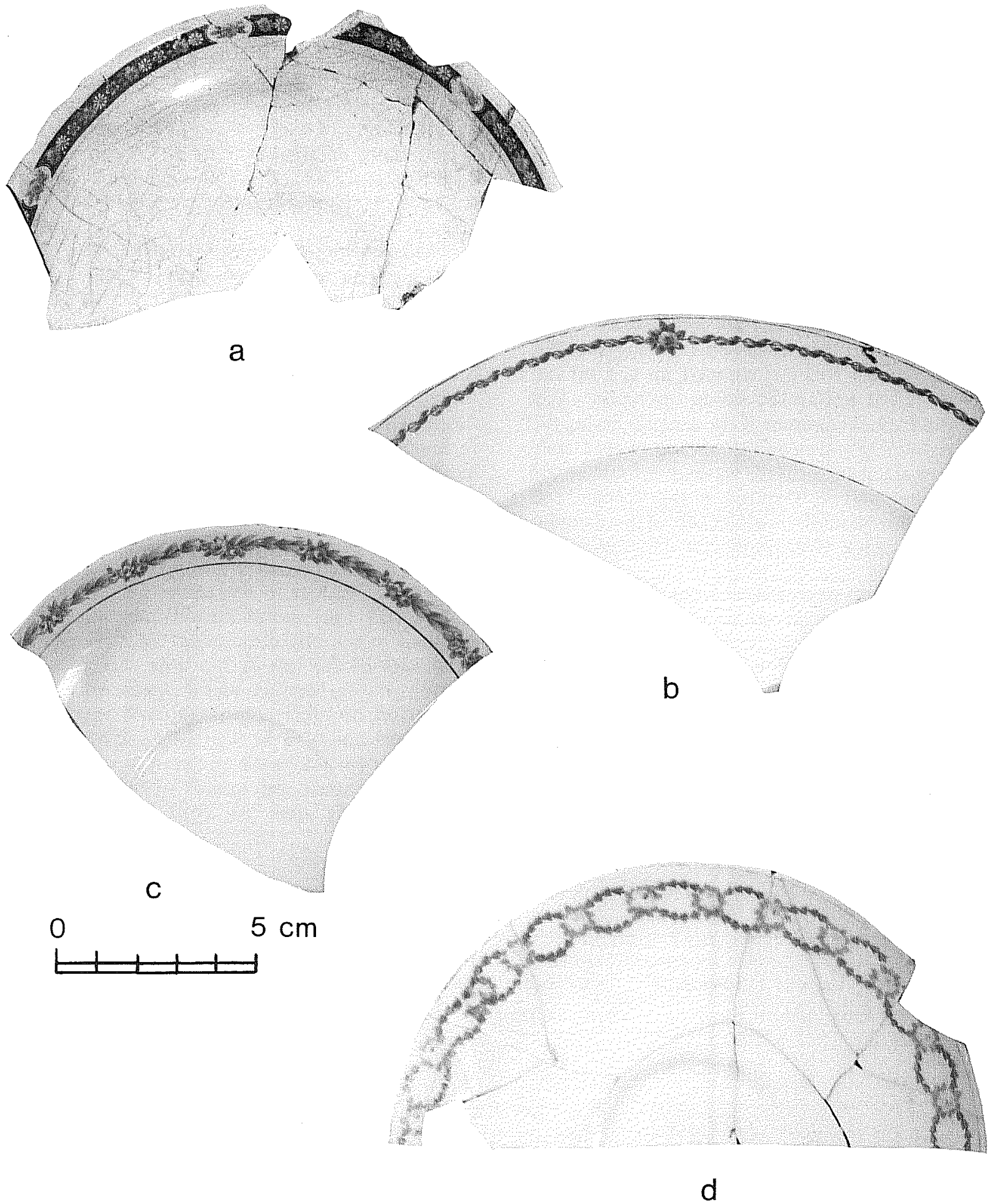

Figure 6. Decorated Ceramics from Trench $A$. a, blue, pink, and green decal whiteware saucer fragment with the inscription, "THE ROWLAND \& MARCELLUS .../STAFFO .../ENG...." The mark refers to a New York importing firm ca. 1900 to 1910 (Ray 1974:91), Trench A, Level 1; b, pink and green decal, gold band porcelain plate sherd, Trench A, Level 2; c, pink and green decal, gold band saucer sherd with the inscription, "JOHNSON BRO./ENGLAND," Hanley Staffordshire, ca. 1913 + (Godden 1964:356), Trench A, Level 2; d, pink and green decal, gold band porcelain saucer sherd with the inscription, "VICTO.../AUS...." The mark is from the Porcellanfabrik Victoria factory, Alt-Rohlau, Bohemia (Ray 1974:239), Trench A, Level 2. 
A comparison of the percentages of ceramics recovered from the various trenches and those recovered from the Schuetz excavation (Table 7) permits some interesting observations (Trenches B and $C$ were not included as only a few artifacts were collected). Despite the fact that we are comparing screened deposits (Schuetz, Trench A and Trench D) with a randomly collected sample (Trench F), certain observations can be made.

The recovery of a few 18th-century sherds (Goliad ware, lead and tin glazed) from the Schuetz and Trench $A$ excavations probably indicates they were present in the soil in this area, since they were recovered from the upper fill levels, rather than from the bottom of the ditch. This also suggests that the surrounding soil was scraped up and thrown into the ditch during the filling operation. Soil removed from the bottom of the acequia during the annual draining and cleaning operation would likely have contained such sherds washed down from the area of the mission. Deposits of this dredged soil built up in low mounds on either side of the acequias during their time of active use for irrigation in the 18th century.

The ceramic percentages from Trench $\mathrm{A}$ are clearly different from those of the other excavations. This is particularly apparent in the case of porcelain, which was much more plentiful. The fact that the ceramic percentages from Trench A differ markedly from those of the Schuetz excavation just upstream and the fact that there was no cross-matching of patterns between the two collections, suggest that although not far apart, these deposits came from different households. A visual comparison of the two confirms that the Trench A collection also includes a much greater variety of decorated whitewares and porcelains (Ellis 1989), suggesting if not a wealthier household, certainly one that had access to a broader choice of wares. These observations led us to do a more detailed analysis of the surrounding neighborhood, with particular emphasis on the residents on either side of the acequia in the tested area.

The neighborhood had passed its prime by 1914 to 1916. The families of many of the original homeowners had grown up and left and in several cases the man of the house had died, leaving his widow to live alone in the house. Some of the houses had been sold to others, and many now were rented to working-class families. Along South Alamo Street, small businesses were beginning to appear, either taking over one of the original houses, as at 444 South Alamo Street, or as an adjunct to a residence in the case of 514 South Alamo Street (Table 8).

In order to understand the circumstances of the deposition of the Schuetz and present test trench collections, we had to determine the households from which they could have come. Based on research in the city directories, Table 8 lists the occupants of the lots in the area served by the section of the acequia under study, with some indication of their socioeconomic level. An approximation of a household's socioeconomic status can be made based on the occupation of the head of the house, the quality of the house, and whether they own or rent the property

TABLE 7. CERAMIC COMPARISONS

\begin{tabular}{|c|c|c|c|c|c|c|c|c|}
\hline & Unglazed & Burnished & Lead Glazed & Tin Glazed & Whiteware & Porcelain & $\begin{array}{l}\text { Stoneware } \\
\text { Yelloware }\end{array}$ & Total \\
\hline \multicolumn{9}{|l|}{ Schuetz (1966) } \\
\hline Count & 7 & & $\begin{array}{l}8 \\
3\end{array}$ & & $\begin{array}{r}102 \\
41\end{array}$ & 15 & $\begin{array}{r}114 \\
46\end{array}$ & 246 \\
\hline Percentage & 2 & & 3 & & 41 & 6 & 46 & 100 \\
\hline \multicolumn{9}{|l|}{ Trench A } \\
\hline Count & 11 & 5 & 12 & 3 & 422 & 114 & 76 & 643 \\
\hline Percentage & 1.7 & 0.8 & 2 & 0.5 & 65.6 & 17.7 & 11.7 & 100 \\
\hline \multicolumn{9}{|l|}{ Trench D } \\
\hline Count & & & & & 17 & 5 & 23 & 45 \\
\hline Percentage & & & & & 38 & 11 & 51 & 100 \\
\hline \multicolumn{9}{|l|}{ Trench F } \\
\hline Count & & & & & 16 & 5 & 20 & 41 \\
\hline Percentage & & & & & 39 & 12 & 49 & 100 \\
\hline
\end{tabular}


TABLE 8. RESIDENTS IN STUDY AREA*

\begin{tabular}{|c|c|c|c|}
\hline Street & Number & 1914 & 1916 \\
\hline South Alamo Street & 434 & $\begin{array}{l}\text { Mrs. S. E. Eager (owner), } \\
\text { Widow Robert, rancher }(1)^{* *}\end{array}$ & Mrs. S. E. Eagar (owner) \\
\hline South Alamo Street & 440 & $\begin{array}{l}\text { Alex Goodman (renter), } \\
\text { traveling salesman (4) }\end{array}$ & R. and Candelaria Leos (renter), tailor (4) \\
\hline South Alamo Street & 444 & $\begin{array}{l}\text { San Antonio Poster Advertising } \\
\text { Co. (renter) }\end{array}$ & Joe and Jacinta Macias (renter, tailor (4) \\
\hline South Alamo Street & 502 & $\begin{array}{l}\text { Mrs. Anna S. Pereida (owner), } \\
\text { Widow R. M., jeweler (3) }\end{array}$ & Mrs. Anne S. Pereida (owner) \\
\hline South Alamo Street & 506 & $\begin{array}{l}\text { Mrs. J. S. Winlack (owner), } \\
\text { Widow J. R., engineer (1) }\end{array}$ & $\begin{array}{l}\text { L. F. and Rose Birdsong (owner), Potchernick- } \\
\text { Birdsong (2) }\end{array}$ \\
\hline South Alamo Street & 514 & $\begin{array}{l}\text { Mrs. Minnie Hein (renter), } \\
\text { confectionary and restaurant (4) }\end{array}$ & Mrs. Minnie Hein (renter) \\
\hline Goliad Street & 221 & $\begin{array}{l}\text { Mrs. A. E. Dewees (owner), Widow } \\
\text { John O., rancher (1) }\end{array}$ & Mrs. A. E. Dewees (owner) \\
\hline Water Street & 509 & $\begin{array}{l}\text { Fred and Erna Krisch (owner), Works } \\
\text { Martin-Wright Electric }(3,4)\end{array}$ & Mrs. Mellie Pegg (renter), Widow John \\
\hline Water Street & Rear & C. and Dela Huser (renter) & A. and Clotinda Cortez (renter) \\
\hline Water Street & 513 & $\begin{array}{l}\text { Pat and Edith Dyer (renter), horse } \\
\text { raiser (4) }\end{array}$ & M. W. and Mattye Shuler (renter), insurance (3?) \\
\hline Water Street & 525 & $\begin{array}{l}\text { Mrs. Lucy Zizik (owner), } \\
\text { Widow Isidore }\end{array}$ & Mrs. Lucy Zizik (owner) \\
\hline Water Street & 529 & $\begin{array}{l}\text { E. } R \text {. and Helen Krause (owner), } \\
\text { machinist ( } 3 \text { ) }\end{array}$ & E. $\mathbf{R}$ and Helen Krause (owner) \\
\hline Water Street & 533 & $\begin{array}{l}\text { L. and Emma Zoellner (owner), } \\
\text { Buyer, Shoe and Hat Co. (4) }\end{array}$ & Mrs. Emma Zoellner (owner), Widow Louis \\
\hline Water Street & 535 & $\begin{array}{l}\text { Robert and Mary Storbeck (renter), } \\
\text { Watchman (4) }\end{array}$ & E. and Anna Rodriguez (renter) \\
\hline Water Street & 539 & $\begin{array}{l}\text { W. and Elizabeth Lorenzen (owner), } \\
\text { Alamo Tent and Awning Co. (2) }\end{array}$ & W. and Elizabeth Lorenzen (owner) \\
\hline Water Street & Rear & $\begin{array}{l}\text { Julius and Lena Lorenzen (renter), } \\
\text { Son - Manager, Alamo Tent and } \\
\text { Awning Co. }\end{array}$ & Julius and Lena Lorenzen (renter) \\
\hline
\end{tabular}

${ }^{*}$ Sources for this information are City Directories for 1914-1915 and 1916-1917 (Appler 1915, 1917); data were collected in 1914 and 1916, respectively.

**Numbers in parentheses correspond to socioeconomic status determination in Table 9. 
(Spencer-Wood and Heberling 1987:59). Henry (1987:367) has suggested seven occupational categories to be used for comparative analysis of consumer behavior in turn-of-the-century sites (Table 9). While these are obviously only approximations, they can be useful in this case in order to better understand the changes taking place in the area and the possible effect on the types of artifacts recovered.

It should be remembered that there are factors other than socioeconomic status that bear on the possible assortment of artifacts discarded by a household. The life cycle of a family from newly married through child raising and the point when the children leave until, as is so often the case, the widow lives alone or goes to live with a married child, has an effect on the types of artifacts present in the home and on the probability of their being discarded (Henry 1987:362; LeeDecker et al. 1987:249). While not as strong an influence as purely economic factors, these factors must be taken into consideration when comparing family discards. Unfortunately, it is nearly impossible to assign the contents of the fill in any one section of an acequia to a particular household on the basis of proximity alone, since there was always at least one household on each side that would have had access.
The area excavated by Schuetz lay between the back lot of 221 Goliad Road on the west and the back property line of 509 Water Street on the east (Fig. 7). The resident at 221 Goliad Road in the 1914 to 1916 time period (Table 8) was the widow of John O. Dewees, a prominent South Texas rancher who owned 24,000 acres in Wilson and Atascosa Counties. Mr. Dewees had died in 1899 (Webb 1952:495), leaving his widow to occupy their large, two-story home alone. The ownership of a large quantity of land and an imposing house indicates a comparatively high standard of living on the level of Henry's (1987) category 1 (professional, high white-collar; Table 9). Henry would classify Mrs. DeWees' status as "unemployed." In this case, the status of unemployed does not carry with it the present-day implication of poverty as well. The widow Dewees probably continued to live through the early 1900s in the manner to which she had been accustomed when her husband was alive. Any ceramics she was discarding would have been primarily things she had acquired before the turn of the century, since she would probably not be in a position where she needed to purchase new ones.

Across the acequia, at 509 Water Street in 1914 lived the Krisch family and the Husers, who rented a house from them near the rear of the lot. Mr. Krisch worked for an electrical contracting firm,

TABLE 9. SOCIOECONOMIC STATUS DETERMINATION*
Number
Determination
Socioeconomic Condition

$\begin{array}{ll}1 & \text { Professional, high white-collar } \\ 2 & \text { Proprietary and low white-collar } \\ 3 & \text { Skilled trades } \\ 4 & \text { Semiskilled and unskilled } \\ 5 & \text { Unclassifiable } \\ 6 & \text { Unemployed } \\ 7 & \\ & \text { Occupation not recorded }\end{array}$

e.g., banker, lawyer, physician

e.g., storekeeper, clerk, teacher

e.g., carpenter, tinsmith, engineer

e.g., waiter, teamster, laborer

job title is unclear or only work place listed

includes the jobless, as well as students, widows, housewives, and the retired

\footnotetext{
* "Based on a scale developed by the Philadelphia Social History Project (Hershberg and Dockhorn 1976) which resulted in close correlation between the different rank categories and measurable variables such as level of education, wages, and property owned" (Henry 1987:367).
} 


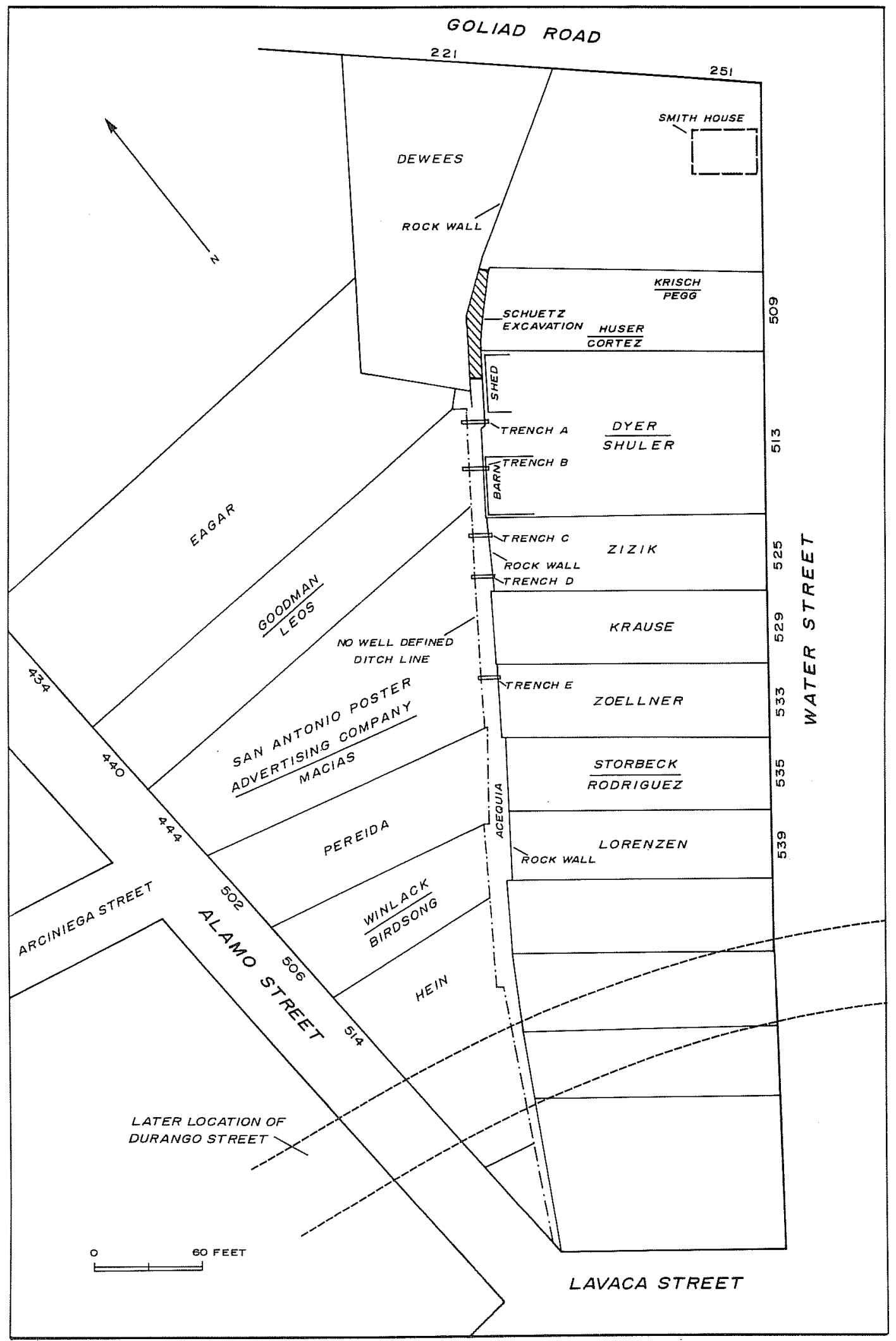

Figure 7. Occupants of the Area, 1914-1916. 
from which we may consider him a skilled tradesman (category 3). By 1916 the Krisches had rented both houses to people of less than moderate means, possibly category 4 level.

The ceramics recovered by Schuetz from this section of the acequia (Table 7) included a comparatively low percentage of porcelain and about equal amounts of whitewares (or ordinary tablewares) and utility or storage wares. As previously noted, these proportions differ from those of the ceramics recovered from Trench A. The reasons for the difference may lie at least partially in the socioeconomic status of the families contributing to the deposits. Shephard (1987:192) has noted that the ratio of table to storage wares was higher for middle class than for lower class families in antebellum Alexandria, Virginia. He reasons that this was due to "an emphasis on display rather than utility." A similar situation may be reflected here, where the deposits were probably primarily from middle class families. However, other influences such as a German tendency toward use of stoneware for kitchen needs may have an influence also. Therefore, it is not possible to draw any definite conclusions on the source of the deposits based on the surrounding household information.

Trench A was located between the lot at 513 Water Street on the east and the lot at 440 South Alamo Street on the west. The relatively small exposure of the lot at 434 South Alamo Street to the acequia probably rules out any major influence from that direction.

The house at 440 South Alamo Street was rented in 1914 to Alex Goodman, a traveling salesman (Table 8). By 1916, the renters were a tailor, $\mathbf{R}$. Leos, and his wife. Neither of these households would be likely to be able to afford the proportionately large amount of expensive ceramics such as imported porcelains and decorated whitewares recovered from the acequia fill (Table 1).

Across the acequia at 513 Water Street in 1914, Pat Dyer, a horse raiser, and his wife were renting the large, two-story home originally built by Gustave Schmeltzer in 1876 (Hagner 1940:68). A prosperous merchant, Schmeltzer founded the firm of Hugo and Schmeltzer which operated a large mercantile store on the site of the Alamo for a number of years. By 1914, his widow was no longer living in the family home, and it was rental property. In 1916, the house was rented to M. W. Shuler, an insurance agent, and his wife.

It is difficult to account for the large proportions of more expensive ceramics in the deposits, considering the probable limitations of the household budgets of the families occupying the site. One possible explanation exists in the previous occupation and continued ownership by the Schmeltzer family, who would have had the income and social status not only to afford but actually to require the finer ceramics. Added to this was the ready accessibility of fine imported goods through their ownership of the store in the late 19th century and probably continued contact with suppliers up to the time of Mr. Schmeltzer's death in 1911. When the family moved out in preparation for renting the house, trash may have been discarded toward the back of the lot, or stored in a barn or shed in the vicinity and this was later used to fill the acequia. The presence in the fill of Trench $A$ of 18th-century materials dredged from the acequia in earlier times suggests that the surrounding soil and any accompanying trash were scooped up and deposited together in the empty acequia when it was being filled.

\section{DISCUSSION OF THE ARTIFACT COLLECTION}

As mentioned previously, the artifacts recovered from the test trenches, when examined as a whole, make a statement about the types of materials available to households in San Antonio in the early 20th century. A representative group of artifacts other than ceramics is illustrated in Figures 8 and 9.

The invention of bottle-making machines in the early 1900s introduced a new era into the production of glass containers. Clear glass bottles and jars (Fig. 8,a, b, e) became very cheap, and it was no longer sensible to save and refill these containers again and again. Trash deposits were suddenly made up of large quantities of clear container glass. As the process of blowing bottles into a mold and finishing the neck by hand (Fig. 8,c, d) was phased out, so also was the custom of molding the name of the product and its producer on the bottle. Mass-produced bottles then received paper labels.

Examples of artifacts representing household furnishings include clothes hooks, clock parts, light bulb and lamp parts, and hardware such as an ornamental disk used to mount a drawer pull (Fig. 9 ,a) and a latch from a wooden cabinet door (Fig. 9,b). A clothes pin spring (Fig. 9,k) is also included in this category, as well as an unidentified metal fastener meant to attach a rod-shaped object to a flat object (Fig. 9,m).

Clothing-related artifacts include the usual porcelain and shell buttons, metal buckles, a bone 


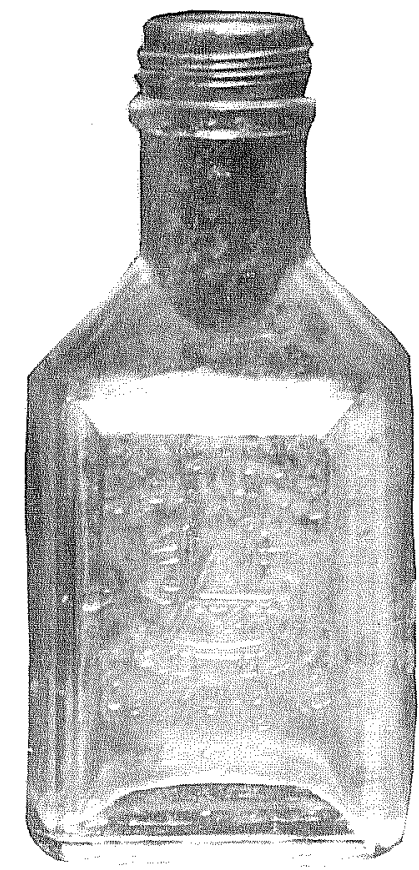

a

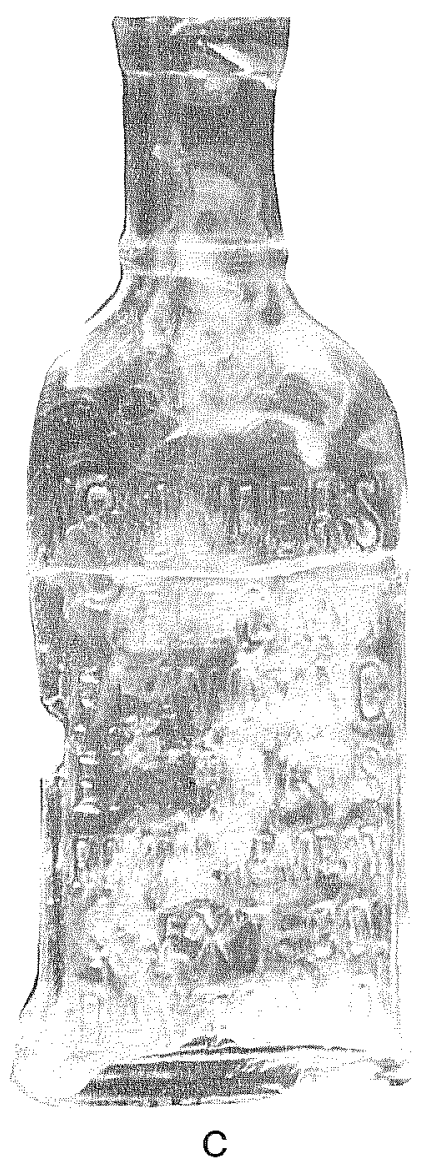

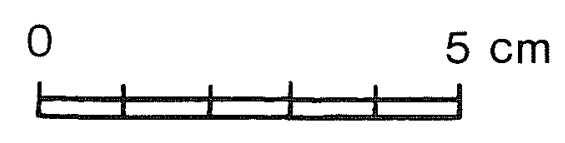

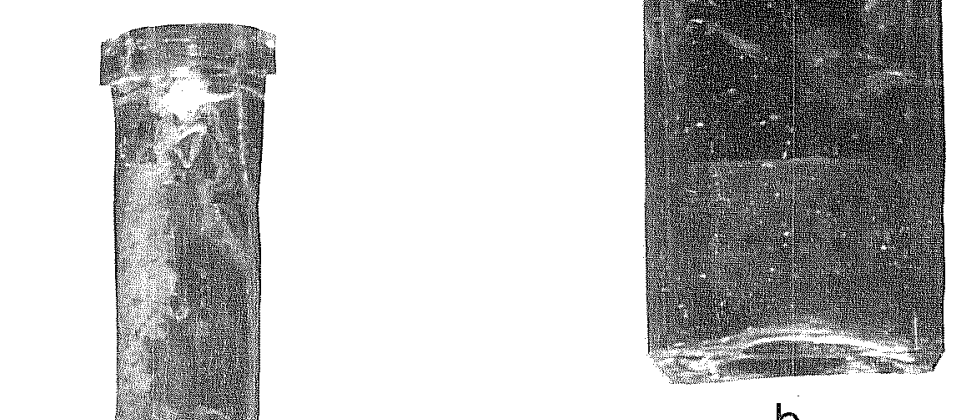

b

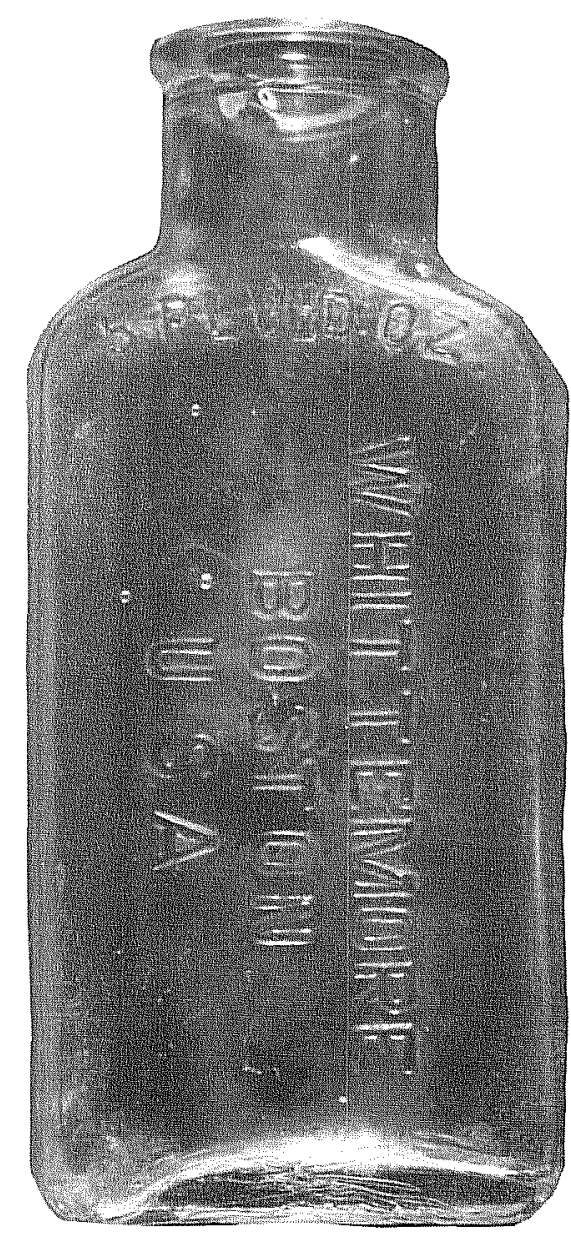

e

Figure 8. Typical Bottles from the Test Excavations. a, machine-made, clear "A.A. HINDS/PORTLAND ME/USA" Product introduced in 1875. Company absorbed by Lehn \& Fink, Bloomfield, New Jersey, in 1907 (Fink 1987:92), Trench A, Level 1; b, machine-made clear medicine, Trench B; $c$, blown-in-mold clear "SOUDERS/ELEGANT/FLAVORING/EXTRACTS/ ROYAL REMEDY/\& EXT.CO./DAYTON, O." No data found on this inscription, Trench D; d, blown-in-mold aqua olive oil, Trench B; e, machine-made clear "WHITTEMORE/BOSTON/USA." No data found on this inscription, Trench B. 
Figure 9. Miscellaneous Artifacts from the Test Excavations. a, ornamental boss for drawer pull, Trench A, Level 1; b, cabinet latch, Trench A, Level 1; c, bone collar button, Trench A, Level 3; d, wooden spool fragment, Trench A, Level 2; e, decorative object of polished bone, Trench A, Level 2; f, barret with rhinestones, Trench A, Level 1; g, glass perfume applicator, Trench A, Level 1; h, ceramic pipe bowl fragment, Trench A, Level 3; i, trolley token, Trench C; $j$, brass tag for fire alarm key with inscription: "RETURN TO/ALAMO INS. CO./SAN ANTONIO, TEX./OWNER/WILL PAY 50® REWARD." Reverse, "ALAMO FIRE INS/CO. BUILDING/210." Alamo Fire Insurance Company, Sam Maverick president, was organized ca. 1890 (Engelhardt 1891:41); $\mathrm{k}$, clothes pin spring, Trench A, Level 1; l, brass strap guide, Trench A, Level 1; m, unidentified metal fastener, Trench A, Level 1; n, glazed porcelain doll's leg, Trench A, Level 1; o, bisque porcelain doll's leg, Trench A, Level 1; p, bisque porcelain baby doll's leg, Trench A, Level 1; q, iron horse's head, Trench A, Level 1. 


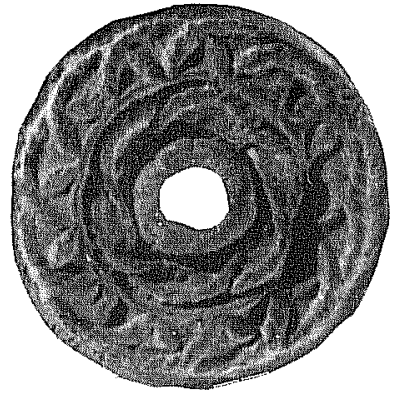

a

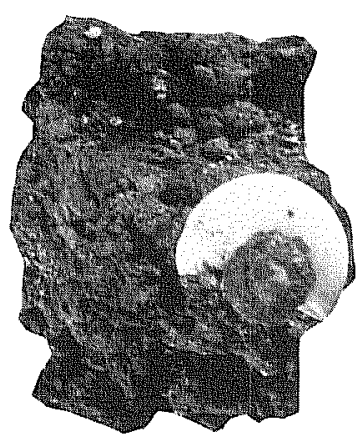

b
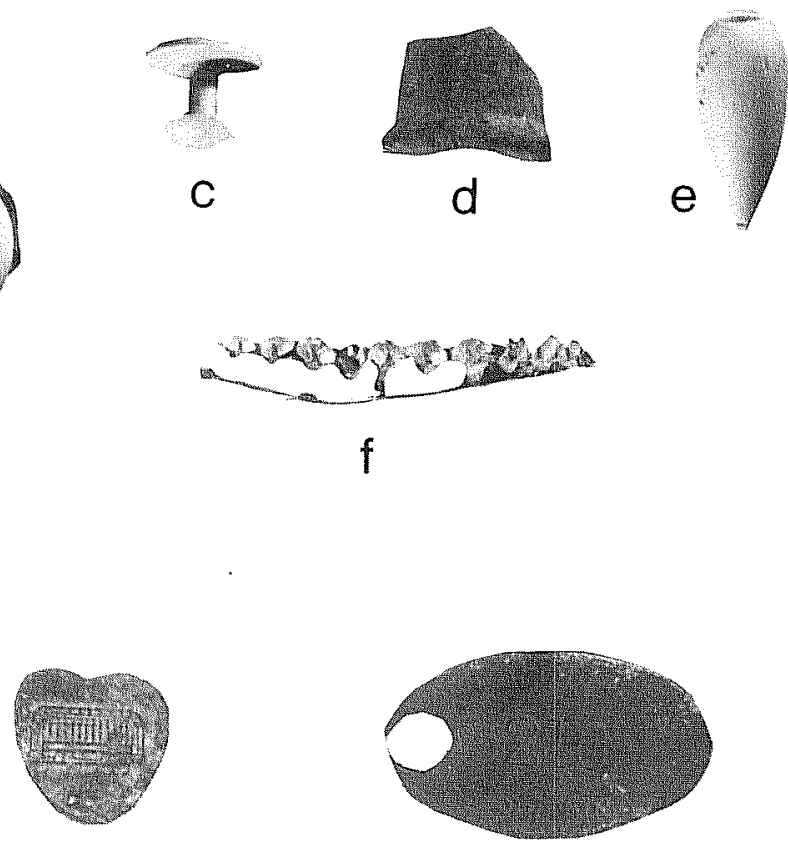

g

h

i
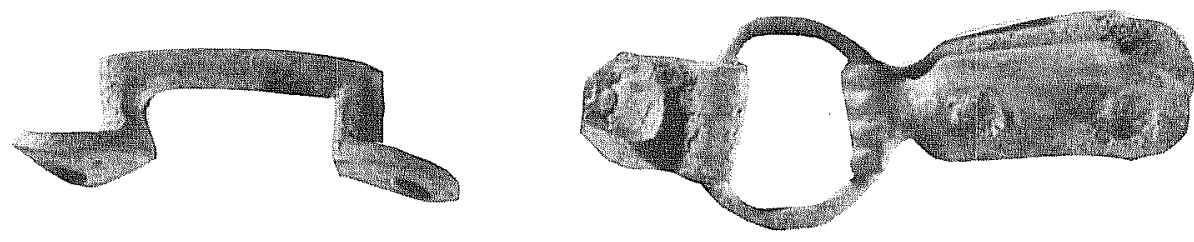

k

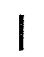

$m$
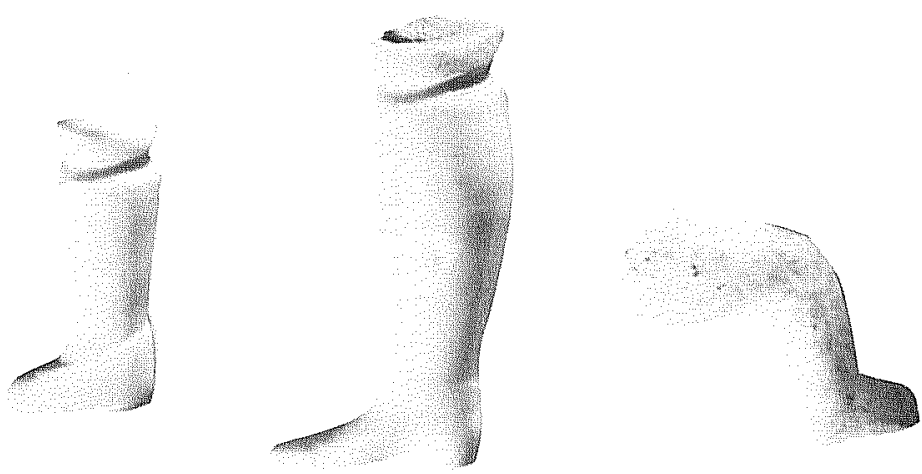

$n$

0

$p$
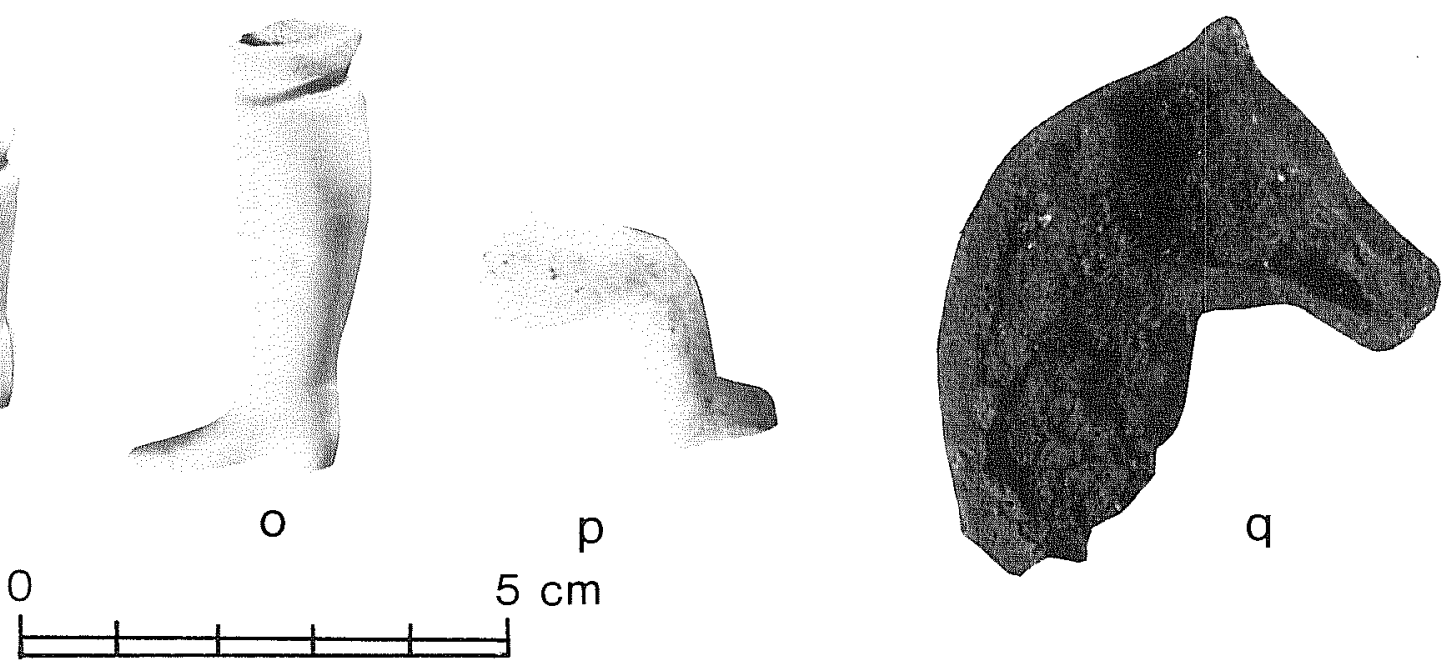
collar button (Fig. 9,c), a tailor's chalk, and a fragment of a spool for thread (Fig. 9,d). An unidentified polished bone object (Fig. 9,e) appears to have been fashioned to be attached to the end of a decorative tie or string.

Personal objects include jewelry, such as a pin or barrette set with rhinestones (Fig. 9,f) and a number of glass beads. Fragile glass applicators from perfume bottles (Fig. 9,g), a number of metal lipstick tubes, broken bone toothbrush handles and composition combs, and a broken hook from a garterbelt represent women's objects. The men of the family are represented by a fragment of a clay smoking pipe (Fig. 9,h), a trolley token (Fig. 9,i), and a brass tag that was once attached to the key of a fire alarm (Fig. 9,j). Such keys were issued to subscribers to a "fire insurance" company so that the alarm could be rung when necessary to summon the fire engine.

Children are represented by a number of porcelain doll parts (Fig. 9,n-p), a fragment of a doll's tea set, marbles, slate fragments, a lead soldier, and part of a molded iron horse (Fig. 9,q).

Objects that could be related to the back yard workshop or barn were not particularly noteworthy. These include rivets, grommets, and other fastening devices, a brass strap guard probably from a wagon, and fragments of wire and scrap metal. Shotgun shells and cartridge cases were also present in the deposits, representing the activities of the men of the household.

Construction materials consist of the usual nails and window glass, floor tile, and roofing materials. Numerous fragments of porcelain insulators indicate that electricity had been installed in at least one of the surrounding homes by 1914 .

\section{CONCLUSIONS}

This project has demonstrated that the acequia is still present and capable of yielding important information despite the fact that one wall has been totally stone-robbed in this section. Apparently the stone removal took place at some time after the trash deposits were accumulated, but before a map drawn in 1915 (City of San Antonio, Texas 1915) which shows "no well defined ditch line" where the west wall should be.

In answer to the three research questions posed as part of the research design, the following observations can be made. It appears from analysis of the materials recovered by Schuetz in 1966 and those recovered by this project that the trash fill in the acequia was deposited in a single operation after the ditch no longer carried water.
We were able to determine that there were differences in the fill at different locations and that at least some of these differences could be attributed to variations in socioeconomic status of the surrounding households. Although these differences could be measured and to some extent explained, it was difficult to attribute trash deposits to individual households. In the case of Trench A, there is a strong possibility that the deposits can be attributed to the Schmeltzer family, because of the unusually high quality and variety displayed by the ceramics recovered. However, this is tenuous as far as the rest of the artifact collection is concerned.

\section{RECOMMENDATIONS}

Since the plan for the park includes removing the ca. three feet of fill over the acequia, rebuilding the walls, and paving it to carry water, we feel that the most intensive part of the acequia fill will probably be preserved in place through most of its length within the park (Fig. 3). The materials already recovered are an adequate sample to indicate how and when the acequia was filled and constitutes an interesting study collection for further analysis in comparison with materials taken from other sections of this and other acequias in San Antonio. The section of the Alamo Acequia Madre that is included in the HemisFair Park should be made a State Archeological Landmark and considered for nomination to the National Register of Historic Places. Undoubtedly, other sections of this acequia are still intact beneath the surface and should be protected from further disturbance by future park construction.

Once the archaeological testing was finished, the architects used the resulting map and profiles of the acequia channel to draw plans for a park in this section of the HemisFair grounds. Stonemasons raised the acequia walls to a level slightly above the present ground surface and poured a concrete bottom for a shallow channel to carry recirculating water through the northern half of the area. The concrete caps the top of the archaeological deposits (Level 4 in Fig. 3). At the time that this was done, hopes were expressed that eventually the rest of the acequia to the south within the park could be treated in the same way. If this is to be done, or if any other changes are planned in this area, care must be taken not to disturb or remove what is left of the acequia and its contents. 


\section{REFERENCES CITED}

Appler, J. A., compiler and publisher

1915 Jules A. Appler's General Directory and Householder Directory of Greater San Antonio. San Antonio.

1917 Jules A. Appler's General Directory and Householder Directory of Greater San Antonio. San Antonio.

City of San Antonio, Texas

1915 Map of C.B. 889, 890, and 127. Showing property conveyed to owners along Alamo Ditch. Copy on file at City Engineer's office; photocopy in files of Center for Archaeological Research, The University of Texas at San Antonio.

Council of Texas Archeologists (CTA)

1981 Guidelines for Curation Standards and Procedures. Council of Texas Archeologists, Newsletter 5(2).

Cox, I. W.

1985 10th Street Substation Excavation of the Acequia Madre (41 BX 8), San Antonio, Bexar County, Texas. Center for Archaeological Research, The University of Texas at San Antonio, Archaeological Survey Report 153.

1986 Excavations of Portions of the San Pedro Acequia (41 BX 337) and a Search for the Arocha Acequia, San Antonio, Texas. Center for Archaeological Research, The University of Texas at San Antonio, Archaeological Survey Report 161.

Cox, I. W. and A. A. Fox

1983 Literature and Archival Study for the Development of HemisFair Plaza, San Antonio, Texas. Center for Archaeological Research, The University of Texas at San Antonio, unpublished manuscript on file.

Ellis, D. B.

1989 A Study of the Ceramics from the Alamo Acequia Madre. Center for Archaeological Research, The University of Texas at San Antonio, unpublished manuscript on file.
Engelhardt, G. W.

1891 The Engelhardt Series: American Cities, San Antonio, Texas. Reprinted by Norman Brock, San Antonio, 1977.

Fink, R. E.

1987 The Bottle Book. A Comprehensive Guide to Historic, Embossed Medicine Bottles. Peregrin Smith Books, Salt Lake City, Utah.

Fox, A. A.

1985 Testing for the Location of the Alamo Acequia (41 BX 8) at HemisFair Plaza, San Antonio, Texas. Center for Archaeological Research, The University of Texas at San Antonio, Archaeological Survey Report 142.

Fox, A. A., I. W. Cox, L. Highley, and D. Hafernik 1989 Archaeological and Historical Investigations at the Site of the New Bexar County Justice Center in Downtown San Antonio, Texas. Center for Archaeological Research, The University of Texas at San Antonio, Archaeological Survey Report 184.

Fox, D. E., F. Valdez, Jr., and L. O. Bobbitt

1978 An Archaeological Assessment of the Dolores Aldrete House Property, San Antonio, Texas. Center for Archaeological Research, The University of Texas at San Antonio, Archaeological Survey Report 58.

Frkuska, A. J., Jr.

1981 Archaeological Investigations at the San Pedro Acequia, San Antonio, Texas. Center for Archaeological Research, The University of Texas at San Antonio, Archaeological Survey Report 103.

Gates, W. C., Jr., and D. E. Ormerod 1982 The East Liverpool Pottery District: Identification of Manufacturers and Marks. Historical Archaeology 16(1-2).

Godden, G. A.

1964 Encyclopaedia of British Pottery and Porcelain Marks. Bonanza Books, New York. 
Habig, M. A.

1968 The Alamo Chain of Missions. A History of San Antonio's Five Old Missions. Franciscan Herald Press, Chicago.

Hagner, L. M.

1940 Alluring San Antonio, Through the Eyes of an Artist. Naylor, San Antonio.

Henry, S. L.

1987 Factors Influencing Consumer Bahavior in Turn-of-the-Century Phoenix. In Consumer Choice in Historical Archaeology, edited by S. M. Spencer-Wood:359-382. Plenum Press, New York.

Hershberg, T. and R. Dockhorn

1976 Occupational Classification. Historical Methods Newsletter 9(2-3):59-98.

Katz, P. R.

1978 Archaeological Investigations in the Arciniega Street Area, Downtown San Antonio, Texas. Center for Archaeological Research, The University of Texas at San Antonio, Archaeological Survey Report 61.

Kovel, R. M. and T. H. Kovel

1971 Dictionary of Marks on Pottery and Porcelain. Crown Publishers, Inc., New York.

Labadie, J. H., assembler

1986 La Villita Earthworks (41 BX 677): San Antonio, Texas. A Preliminary Report of Investigations of Mexican Siege Works at the Battle of the Alamo. Center for Archaeological Research, The University of Texas at San Antonio, Archaeological Survey Report 159.

LeeDecker, C. H., T. H. Klein, C. A. Holt, and A. Friedlander

1987 Nineteenth-Century Households and Consumer Behavior in Wilmington, Delaware. In Consumer Choice in Historical Archaeology, edited by S. M. Spencer-Wood:233-260. Plenum Press, New York.
Miller, G.

1980 Classification and Economic Scaling of 19th Century Ceramics. Historical Archaeology 14:1-19.

Ray, M.

1974 Collectible Ceramics. Crown Publishers, New York.

Schuetz, M. K.

1970 Excavation of a Section of the Acequia Madre in Bexar County, Texas, and Archeological Investigations at Mission San Jose in April, 1968. Texas Historical Survey Committee, Archeological Report 19.

Shephard, S. J.

1987 Status Variation in Antebellum Alexandria, An Archaeological Study of Ceramic Tableware. In Consumer Choice in Historical Archaeology, edited by S. M. Spencer-Wood:163-198. Plenum Press, New York.

Spencer-Wood, S. M. and S. D. Heberling

1987 Consumer Choices in White Ceramics: A Comparison of Eleven Early NineteenthCentury Sites. In Consumer Choice in Historical Archaeology, edited by S. M. Spencer-Wood:55-84. Plenum Press, New York.

Taylor, F. B., R. B. Hailey, and D. L. Richmond

1966 Soil Survey of Bexar County, Texas. United States Department of Agriculture, Soil Conservation Service, in cooperation with the Texas Agricultural Experiment Station, Series 1962(12).

Webb, W. P.

1952 The Handbook of Texas. Vol. I. The Texas State Historical Association, Austin. 


\title{
APPENDIX
}

\section{ADDITIONAL TESTING}

\author{
Maureen J. Brown
}

\section{INTRODUCTION}

After the trenching of the acequia, further testing was recommended by the staff of the Texas Antiquities Committee in advance of constructing planned landscape features in the vicinity of the remaining houses facing Goliad Road. Four backhoe tests to the west of the acequia revealed that extensive fill had been placed over the area during the construction phase of HemisFair in 1967. The only area that appeared to be at the original ground level was in the vicinity of a small settlement saltbox-style house called the Sam Smith house. The following information taken from a file about HemisFair located at the San Antonio Conservation Society was included in a report by Cox and Fox (1983:13) under the title "Structure 20 (HemisFair \#251)":

This Settlement-Salt Box house of stuccoed soft limestone or caliche is located on the edge of property acquired by John Riddle from Miguel Arciniega in 1841 ( $B C D R$ Vol. A2:402). While it is possible that Riddle built the house, it was most probably constructed by the next owner, Samuel Smith, who purchased the lot in June 1857 ( $B C D R$ Vol. P1:310). Smith, called "El Barbon" or "Big Beard", was once Mayor of San Antonio and later the County Clerk for a long period.

The house originally fronted on Water Street. A backhoe trench in front of the house revealed that the present surface was, in fact, the original surface level. Test pits along the foundation of the house were then excavated to sterile soil.

\section{ARTIFACTS RECOVERED DURING TESTING AT THE SMITH HOUSE}

Only a few artifacts were found during excavation of two $1-\mathrm{m}^{2}$ units (Units $A$ and $B$ ) located in front of the southern wall of the Smith house in HemisFair Park (Fig. 10). The south end of the house was chosen for excavation because it was believed to be the only undisturbed area. The units were placed on the east (Unit A) and west side (Unit B) of the back porch doorstep in hope of finding discarded objects. Both units were excavated to sterile soil (approximately $25 \mathrm{~cm}$ ).

As seen in Table 10, more artifacts were recovered from Unit A than Unit B. Both units contained some disturbance because, as seen in Figure 10, there was a pipe that ran in an east-west direction on the north end of both units. However, Unit B contained more disturbance because it was located at the midpoint of where an additional room was added to the back of the house.

\section{CERAMICS}

\section{Unglazed Ware}

One red paste unglazed flower pot rim was found in Unit B. This sherd was wheel-turned and looks to be a fairly recent ceramic artifact.

\section{Lead-Glazed Ware}

Two very small and thin lead-glazed earthenware sherds were included in Unit A. One is a rim sherd with an interior and exterior glaze, and the other is a body fragment. Because of their size it is difficult to determine their vessel form. They are both possibly fragments of toy vessels.

\section{Ironstone}

Four undecorated ironstone earthenware fragments are included in this collection. One rim sherd and one basal sherd from a plate were found in Unit A. Unit B contained a rim fragment from a molded cup and a sherd from a plate base. No maker's marks are included on these fragments. Undecorated ironstone became popular during the later half of the 19th century. 


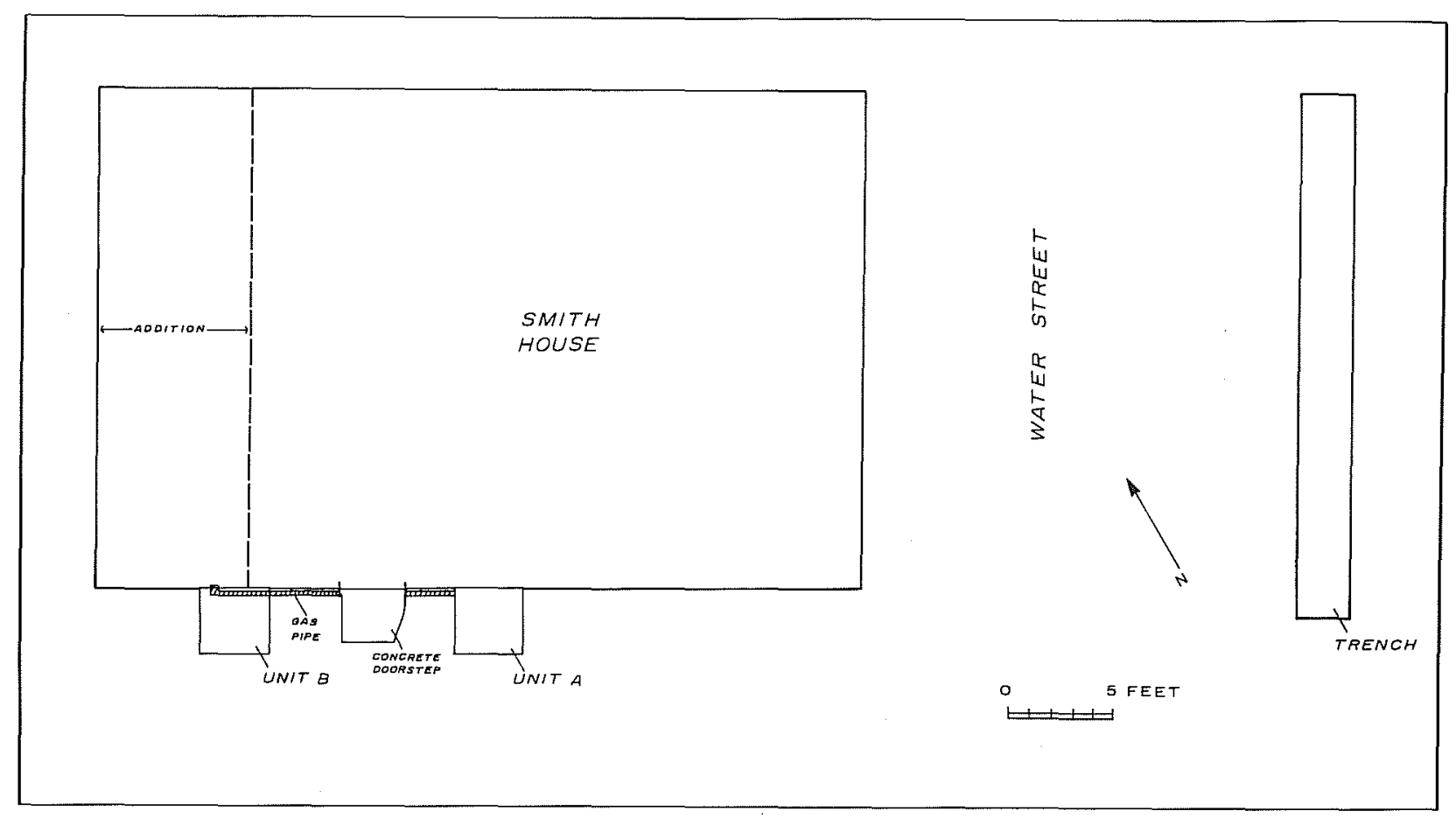

Figure 10. South Wall of Smith House and Test Units.

\section{Yelloware}

One unglazed yelloware body fragment was found in Unit A. This sherd is believed to be a flower pot fragment.

\section{GLASS FRAGMENTS}

All glass that was found in Units A and B consisted of small fragments. These were divided into color groups. The brown glass fragments are from recent beer bottles, whereas some of the clear and aqua fragments have a heavier thickness and are from an earlier time. The only distinguishable glass forms are two very thin light bulb glass fragments (Units $A$ and $B$ ) and 13 window glass fragments (12 in Unit A, one in Unit B).

\section{BONE}

Fifty-one animal bone fragments (some splinters) were excavated from Unit A. Of these, three appear to be burned (one of these was sawed at one end). Only two bone fragments were in Unit B. Most of these fragments are large mammal or bird (chicken) remains. There are two cranial fragments from a large mammal and 14 fowl long bone shaft fragments. The rest of the bone fragments are too small to tell the species type. Since the bone fragments were located near the back door of the Smith house, they were most likely the food remains of the Smith family.

\section{NAILS}

Two different types of nails were found in Units $A$ and $B$. Six cut nails (three each in Units $A$ and $B$ ) and 15 wire nails (12 in Unit $A$ and 3 in Unit B) were excavated. One of the cut nails has a square head, while the others are fragments. The size of the plate-cut nail is four penny weight (4d), and it has a length of $1-3 / 4$ inches. Since the house was built sometime during the 1850 s and cut-plate nails were in use at that time, it is quite possible that these nails were part of the house structure itself.

Wire nails did not see widespread use until late in the 1880s, but by the turn of the century, wire nails became dominant with the exceptance of the specialty trades (Fontana and Greenleaf 1962:50). 


\begin{tabular}{|c|c|c|c|}
\hline ARTIFACT REMAINS & Unit A, Level 1 & Unit B, Level 1 & Total \\
\hline \multicolumn{4}{|l|}{ Activity Items } \\
\hline \multicolumn{4}{|l|}{ Writing Materials } \\
\hline Yellow chalk fragment & 3 & & 3 \\
\hline \multicolumn{4}{|l|}{ Construction Items } \\
\hline Brick (red clay) & 2 & & 2 \\
\hline Nails (cut) & 3 & 3 & 6 \\
\hline Nails (wire) & 12 & 3 & 15 \\
\hline Window glass & 12 & 1 & 13 \\
\hline Wire fragments & 8 & 1 & 9 \\
\hline \multicolumn{4}{|l|}{ Household Furnishings } \\
\hline Flower pot fragments & & 1 & 1 \\
\hline Light bulb glass & 1 & 1 & 2 \\
\hline \multicolumn{4}{|l|}{ Kitchen/Dining Items } \\
\hline Bone & 51 & 2 & 53 \\
\hline \multicolumn{4}{|l|}{ Ceramics } \\
\hline Lead glazed & 2 & & 2 \\
\hline Undecorated whiteware & 2 & 2 & 4 \\
\hline Yelloware & 1 & & 1 \\
\hline \multicolumn{4}{|l|}{ Glass Container Fragments } \\
\hline Aqua & 3 & & 3 \\
\hline Brown & 1 & 6 & 7 \\
\hline Clear & 16 & 3 & 19 \\
\hline Green & 3 & 3 & 6 \\
\hline Tin Can Scrap & 15 & & 15 \\
\hline \multicolumn{4}{|l|}{ Miscellaneous Items } \\
\hline Plastic fragments & 4 & & 4 \\
\hline \multicolumn{4}{|l|}{ Prehistoric Remains } \\
\hline Chert fragments & 3 & & 3 \\
\hline TOTAL & 142 & 26 & 168 \\
\hline
\end{tabular}




\section{CHERT FRAGMENTS}

Two chert fragments were found in Unit A. These include a small tertiary flake and a secondary flake.

\section{DISCUSSION}

The Smith house artifacts appear to be post-1850, which agrees with the period that the house was constructed. The artifacts from this time period are the undecorated ceramics and the cut nails. Both of these were used during the later half of the 19th century. Besides these, and the chert fragments, which may indicate that a prehistoric culture was first in this area, the other artifact remains tend to be early 20 th century to recent times. The recent artifacts, like the brown bottle glass and plastic fragments, help verify that both units had some recent disturbance. The western half of Unit B was especially disturbed because this was the point where the house had a more recent addition added to it. The evidence that very little cultural material was found in this section of the test unit confirms this.

\section{ARTIFACTS FROM THE NORTH END OF THE ACEQUIA}

Table 11 lists the artifacts found while monitoring the uncovering of the acequia channel north of the Schuetz excavation by city workers in preparation for construction of the park. Some artifacts were collected from this work.

\section{TABLE 11. ARTIFACTS FROM ACEQUIA WALLS}

\section{ARTIFACT REMAINS}

EAST WALL

(BACKFILL)
WEST WALL

(BACKFILL)

TOTAL

Barn/Shop/Workshop Items

Machinery Parts

Iron brace

Construction Items

Brick (red clay)

1

Iron railroad stake

Mortar fragment

Nails (cut)

1

1

1

2

Kitchen/Dining Items

Bone

1

1

Ceramics

Ironstone

Porcelain 1

Stoneware

Undecorated whiteware

Glass Container Fragments

Aqua

Clear

Vaseline bottle

Clear with brown

Tin Can Scrap

2

1

1

(n)

(1)

1

1

3

1

1

1
1

1

7

2

2
1
7

2

1

1

1

1

3

1

1

1 


\section{CERAMICS}

\section{Whiteware}

Whitewares are hard-paste refined earthenwares that were generally made in England and exported to the United States. One undecorated whiteware fragment, which is the rim of a plate, was found in the backfill on the east side of the acequia wall.

\section{Ironstone}

Ironstone (also called "Hotel Ware") is a heavier ware than whiteware and was especially popular during the later half of the 19th century. Two fragments of this ware were found in the backfill on the east side of the acequia wall. One sherd is a base to a plate with the inscription ". . . STONE. ..." on the bottom. All we can tell from this mark is that the plate is ironstone. The other fragment is a body sherd.

Porcelain

One porcelain saucer base fragment was found in the backfill from the east wall of the acequia. A partial transfer-printed blue mark on the bottom of the saucer reads "DERBY." From Godden (1964) we find that painted (or thumb transferred) mark was used from 1861 to 1935 , when the King Street factory was taken over by the Royal Crown Derby Company, Ltd. The company's owners were Stevenson and Hancock, 1859 to 1935.

\section{Stoneware}

One burned body fragment was found in the east wall backfill. This sherd was made with a red paste clay, wheel turned, and has an exterior salt glaze. The vessel form cannot be determined.

\section{GLASS CONTAINERS/FRAGMENTS}

Located in the backfill of the east wall was a clear Vaseline bottle (height 2-3/4 inches, base diameter $1-7 / 8$ inches, lip diameter $1-1 / 2$ inches). $R$ aised inscriptions on the bottle include "CHESEBROUGH MFG CO VASELINE." From
Yount (1967) we find that the Chesebrough Mfg. Co. was located in New York. The only other distinctive glass fragment is an aqua-colored medicine bottle neck (lip diameter $3 / 4$ inch).

\section{BONE}

One large innominate or scapula fragment of a cow was located in the east wall backfill. In the west wall backfill was found a large mammal (probably a cow) leg shaft that was sawed at both ends.

\section{METAL}

An iron brace with a hole at each end was found in the east wall backfill.

\section{CHERT FRAGMENTS}

Three chert fragments were found in the west wall backfill. These include a primary (cortex) flake, a secondary flake with a single-faceted platform, and a tertiary flake.

\section{DISCUSSION}

It was very common to throw broken housewares, ceramics, metal and food remains into ditches no longer in use. These remains belonged to the people who owned the houses that were located in the acequia area. Therefore, these artifacts probably date from the time period in which this portion of the acequia went out of use. From these very few artifacts we were unable to date the deposit. It is evident that this portion of the acequia was not used as much for waste disposal as the part of the acequia near the location of the Schmeltzer house.

\section{CONCLUSIONS}

Due to the negligible amount of cultural materials or other evidence of archaeological remains recovered within the north end of the acequia, and in the testing around the Smith house, no further testing is necessary. State Archeological Landmark status is not recommended for this area. 


\section{REFERENCES CITED}

Bexar County, Texas

Bexar County Deed Records (BCDR)

Originals and microfilm in the Bexar County Courthouse, San Antonio, Texas.

Cox, I. W. and A. A. Fox

1983 Literature and Archival Study for the Development of HemisFair Plaza, San Antonio, Texas. Center for Archaeological Research, The University of Texas at San Antonio, unpublished manuscript on file.

Fontana, B. L. and J. C. Greenleaf

1962 Johnny Ward's Ranch: A Study in Historic Archaeology. The Kiva 28(1-2).

Godden, G. A.

1964 Encyclopaedia of British Pottery and Porcelain Marks. Bonanza Books, New York.

Yount, J. L.

1967 Bottle Collector's Handbook and Pricing Guide. Action Printery, San Angelo, Texas. 